\title{
NICHE
}

\section{LANDSCAPES OF SCIENCE}

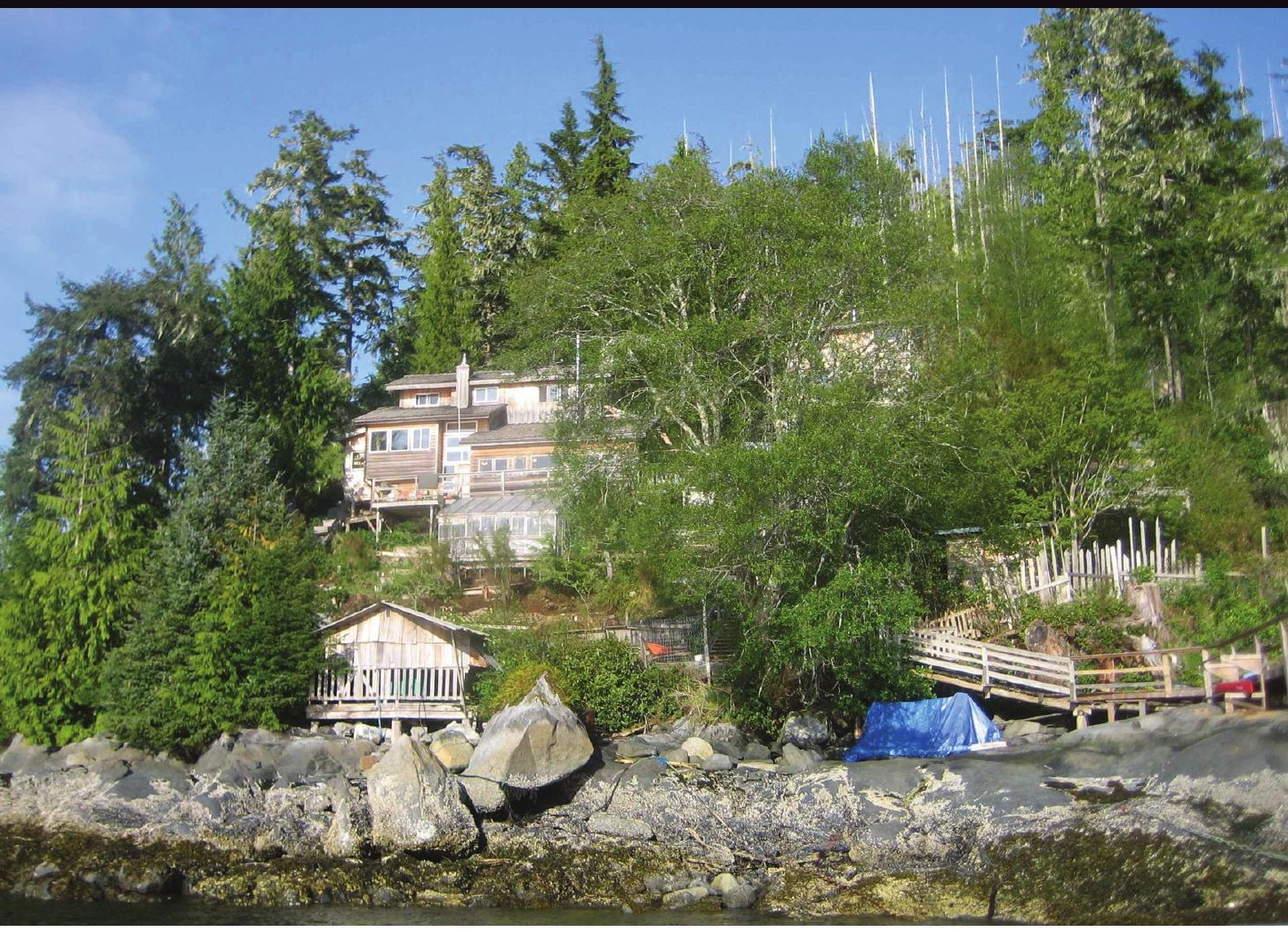

edited by Tina Adcock 


\section{NICHE}

Network in Canadian History and Environment

Department of History

York University

2140 Vari Hall

4700 Keele Street

Toronto, Ontario, M3J 1P3

http://niche-canada.org

Adcock, Tina. Ed. Landscapes of Science. Toronto: Network in Canadian History and Environment, 2018.

DOI: $10.25071 / 10315 / 35685$

\section{(a) $(1)(9$}

Landscapes of Science edited by Tina Adcock is licensed under a Creative Commons Attribution-NonCommercial 4.0 International License.

\section{The Otter La loutre E-book Series}

Editors: Tina Adcock, Sean Kheraj, and Daniel Macfarlane

Layout: Sean Kheraj

Design Consultant: Will Knight

This occasional open-access series collects and preserves the best writing published on The Otter La loutre, NiCHE's blog. Its thematic anthologies feature short pieces that examine the historical relationships among people and the rest of nature in Canada.

ISBN 978-1-9995418-0-4 


\section{Table of Contents}

Preface

Tina Adcock. i

1. Landscapes of Science

Stephen Bocking.. 1

2. The Go Home Bay Biological Station: A Landscape of Science

William Knight. 9

3. Animal Matters: Bovine Smallpox Vaccine at the Connaught Laboratories and University Farm

Joanna Dean. . .18

4. The Herbarium: An Interior Landscape of Science

Peter Anderson 40

5. Met Techs, the Environment, and Science at the Joint Arctic Weather Stations, $1947-1972$

Daniel Heidt.

6. Domesticating Poliovirus: Laboratory Monkeys and Vaccine Production

Liza Piper . .55

Conclusion

Landscapes of Science: Placing Knowledge, Displacing Nature

Stephen Bocking.. .68

Contributors 
Tina Adcock

THIS VOLUME SPRANG from an observation I made on Twitter in November 2014: that the gap between environmental history and the history of science was (and remains) perplexing, given themes of obvious shared interest to these fields. ${ }^{1}$ Researchers such as Michael Egan, Sara Pritchard, and Amy Kohout, whose work bridges this gap, soon chimed in. They offered explanations for this intellectual divergence and shared titles of recent scholarship on the environmental history of science. ${ }^{2}$ Sean Kheraj, meanwhile, had a bright idea: that NiCHE's blog, The Otter La loutre, should publish a series of posts on this subject. As an Otter editor, I took up this challenge.

"Landscapes of Science" premiered in January 2015 with an eponymous post by Stephen Bocking, a leading Canadian scholar in the history of science and the environment. Bocking's overview of this crossdisciplinary subject and agenda for future research elicited a great deal of enthusiasm, as reflected in the numerous, thoughtful replies posted by other environmental historians and historical geographers of Canada. ${ }^{3}$ Two such commenters, William Knight and Peter Anderson, were even inspired to contribute slices of their own research to this series. The posts following Bocking's opening salvo sometimes ranged beyond landscapes of science into adjacent ones of technology and medicine. They generated similarly excellent discussions, and not only among academics. Daniel Heidt's essay on "met techs" working in the High Arctic after the Second World War prompted several members of this community to share memories of their fieldwork. ${ }^{4}$ The high level of engagement with this series 
foregrounds the contemporary relevance and importance of the environmental history of science in Canadian life and letters.

For this reason, as well as the high quality of the series' original research, NiCHE's editorial board wanted "Landscapes of Science" to remain easily accessible for years to come. This e-book is the result. It contains revised versions of the series' five original posts; an expanded version of a cognate post by Joanna Dean, originally published on ActiveHistory.ca; and a new, closing commentary by Stephen Bocking. In concert with other recent Canadian work situated at the intersection of environmental history and the histories of science, technology, and medicine, it aims to guide these fields, slowly but surely, onto common ground. ${ }^{5}$

${ }^{1}$ On the relationship between these two fields, see, for example, Stephen Bocking, "Nature's Stories? Pursuing Science in Environmental History," in Method and Meaning in Canadian Environmental History, ed. Alan MacEachern and William J. Turkel (Toronto: Nelson, 2009), 294-308; Dolly Jørgensen, Finn Arne Jørgensen and Sara B. Pritchard, eds., New Natures: Joining Environmental History with Science and Technology Studies (Pittsburgh: University of Pittsburgh Press, 2013) https://doi.org/10.2307/j.ctt5vkgkn; and Michael Lewis, "And All Was Light?-Science and Environmental History," in The Oxford Handbook of Environmental History, ed. Andrew C. Isenberg (Oxford: Oxford University Press, 2014), 207-26. For my original tweet and ensuing discussion, see https://twitter.com/TinaAdcock/status/529836165860687872.

${ }^{2}$ The titles mentioned were Joshua P. Howe, Behind the Curve: Science and the Politics of Global Warming (Seattle: University of Washington Press, 2014) and Frederick Rowe Davis, Banned: A History of Pesticides and the Science of Toxicology (New Haven, CT: Yale University Press, 2014) https://doi.org/10.12987/yale/9780300205176.001.0001.

${ }^{3}$ For Bocking's most recent thinking on this subject, see Stephen Bocking, "Landscapes of Science in Canada: Modernity and Disruption," in Made Modern: 
Science and Technology in Canadian History, ed. Edward Jones-Imhotep and Tina Adcock (Vancouver: UBC Press, 2018), 251-78.

${ }^{4}$ The original posts with comments are archived at http://niche-

canada.org/tag/landscapes-of-science/. Readers wishing to explore the history and historiography of science and environment in Canada in more depth will find the comments especially illuminating.

${ }^{5}$ See, for example, Ian Mosby and Catherine Carstairs, eds., "Foodscapes of Plenty and Want: Historical Perspectives on Food, Health, and the Environment in Canada," special issue of Canadian Bulletin of Medical History 32, no. 2 (2015) https://doi.org/10.3138/cbmh.32.2.247; Scientia Canadensis 40, no. 1 (2018), a special issue on environmental history and the history of technology co-edited by Daniel Macfarlane and William Knight; and Jones-Imhotep and Adcock, Made Modern, especially the third part, "Environments." 


\section{Chapter 1}

Landscapes of Science

\section{Stephen Bocking}

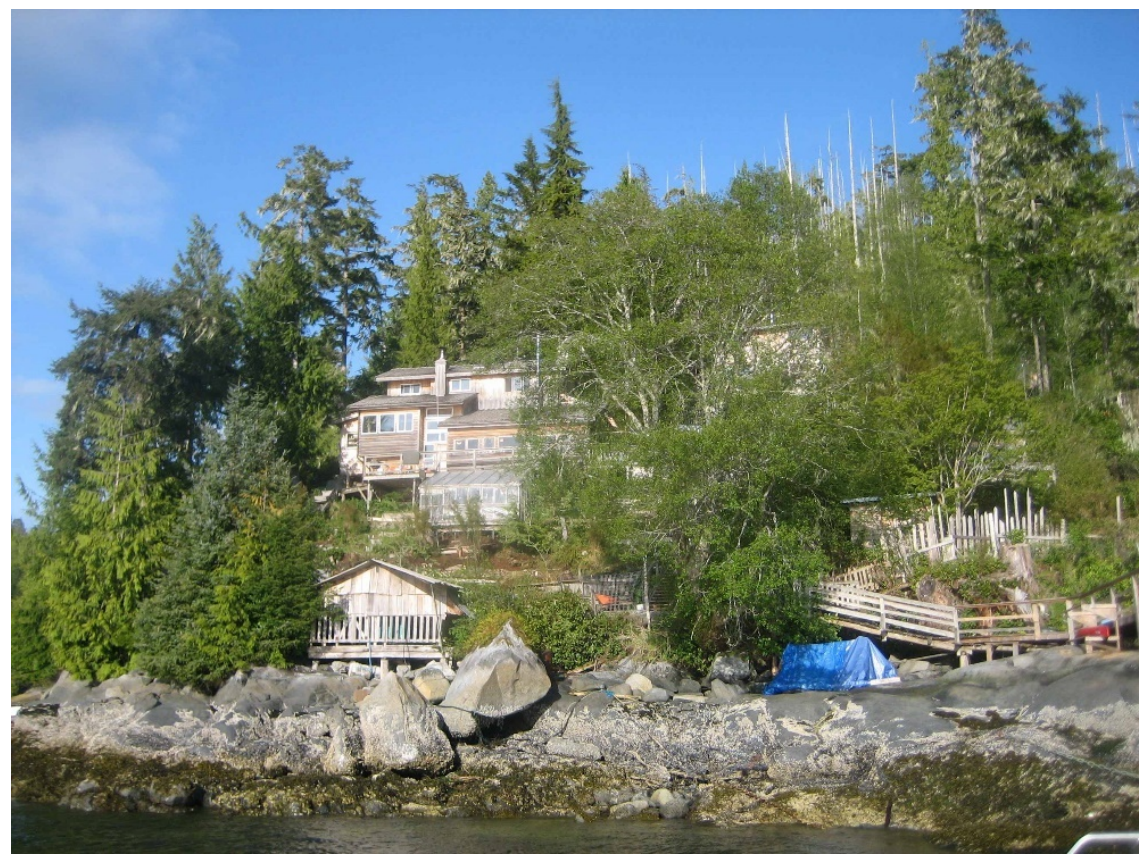

Figure 1. Salmon Coast Field Station, Broughton Archipelago, British Columbia.

Photo: Stephen Bocking.

ON CANADA'S WEST COAST an archipelago of islands and straits sits between northern Vancouver Island and the mainland. In the north, the Mackenzie River meets the Beaufort Sea in a delta landscape of channels, wetlands and lakes. Down east, the woods, fields, and hills of the Oak Ridges Moraine arc across Toronto's suburban sprawl. These are very different landscapes, with distinctive historical patterns of human activity: forestry, fisheries, and salmon farming; fur trapping and oil exploration; 
and urban development. But they all share a history of scientific activity. Like many other places in Canada, they are landscapes of science.

These landscapes remind us that although science is often associated with laboratories, there's an extensive history of scientific work outside, in a variety of environments, taking place for a multitude of reasons. Scientific activity has proliferated in industrial, resource, and urban landscapes, and in places where human activities are less dominant. The questions that scientists ask and the methods they apply in these places have been shaped by their training, disciplinary affiliations, and funding, among other factors. Political and managerial imperatives are also important, such as surveying and asserting national territory, justifying and guiding resource exploitation and management, and tracking the impacts of human activities.

These places also show us how science has been central to key episodes in the environmental history of Canada. Over the last decade, as the Broughton Archipelago became a controversial site for salmon farming, it also attracted intensive research activity. The results of this research, including insights into the implications of sea lice and viruses for farmed and wild salmon, have contributed much to ongoing debates about this industry. ${ }^{1}$ The Mackenzie Delta has been amply studied over the last several decades, partly because of interest in and concerns about oil and gas development. Ever since the Mackenzie Valley Pipeline Inquiry in the 1970s, scientific research and Indigenous knowledge have together shaped attitudes regarding resource exploitation in this region. ${ }^{2}$ And in controversies concerning development of the Oak Ridges Moraine, research, particularly on groundwater, has played a leading role. The environmental history of southern Ontario-including ongoing tensions between development, farming, and the protection of natural areas, now 


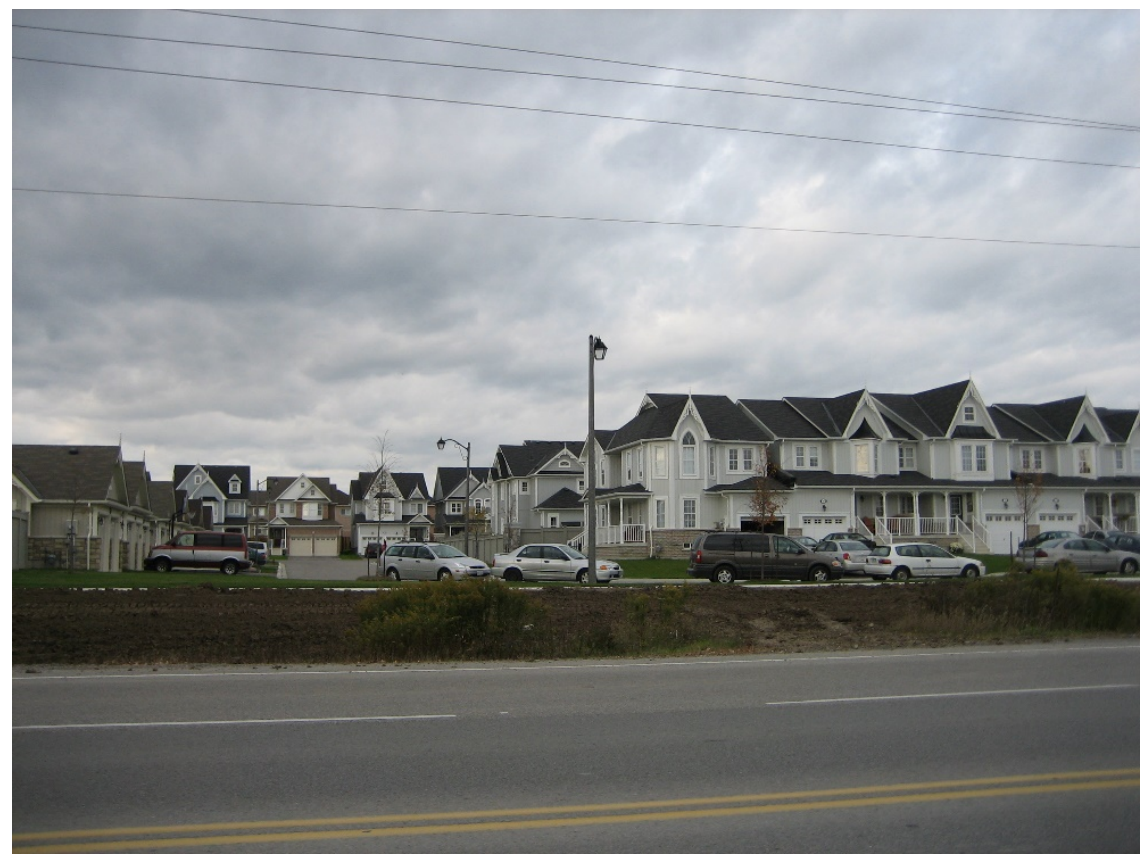

Figure 2. Suburban development on the Oak Ridges Moraine, near Toronto. Photo:

Stephen Bocking.

framed in terms of protecting the Greenbelt that encircles the Greater Toronto Area-continues to reflect these controversies. ${ }^{3}$

Much has been written about the history of science in the Canadian environment. I'm thinking, for example, of Matt Farish's work on military science in the Arctic, Stéphane Castonguay's study of agricultural, forest and entomological science, Caroline Desbiens' analysis of environmental science and the James Bay hydroelectric project, and Richard Rajala's study of forestry. ${ }^{4}$ All of this work combines in different but interesting ways the history of science and environmental history. It shows how science has been linked to historical themes such as Cold War strategic imperatives, the extension of colonial authority, and resource management. But much remains unexamined. What topics and themes deserve more attention in the environmental history of Canadian science? Here are five ideas. 


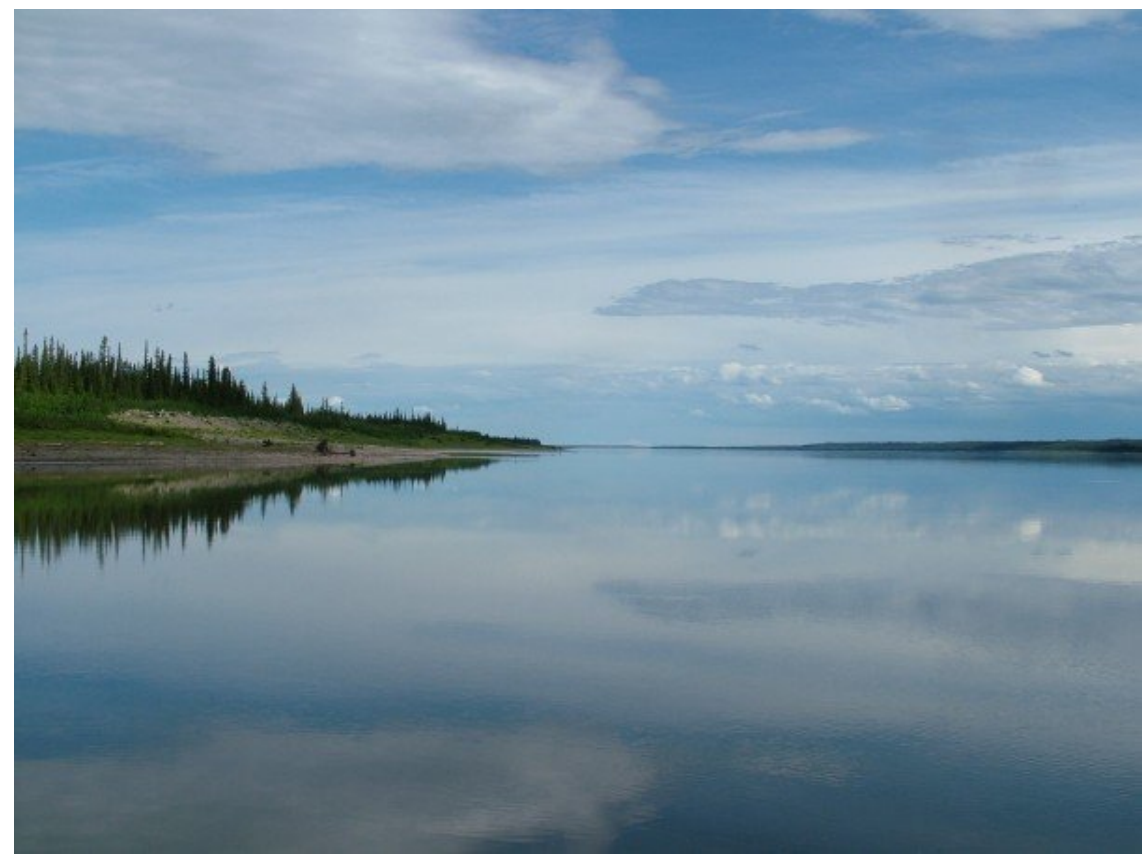

Figure 3. The Mackenzie River on a calm day. Photo: Anson Chappell.

1) The political and economic contexts of science. Discussion of science and politics in Canada was, until recently, dominated by criticism (amply justified) of the Harper government's manipulation and ignorance of science. Today, attention has shifted to the Trump administration's apparently similar, if more extreme, strategy south of the border. ${ }^{5}$ But debates about science policy should be placed in their historical context. This means following the money: paying attention not just to how government funds science, but also to the implications of private funding for environmental research, by industry, foundations, and even wealthy individuals. Although it's likely accelerated in recent years, privatization has in fact been a factor in Canadian environmental science since at least the early 1970s. At that time, the first Trudeau government began shifting research activity from its own agencies to the private sector in an effort to 
build an environmental consulting industry. The nature and implications of this creeping privatization of environmental knowledge for government, public spaces, and civic life remain largely unexamined by historians. Studies of the political economy of environmental knowledge could draw on recent work on the role of corporate science in agricultural and health industries, which has explored the consequences of rearranging everything from genes to ecosystems for profit. ${ }^{6}$

2) Scientists' practices and material cultures. Studying the environmental history of science includes examining what scientists actually do, and with what-how they interact with the environment, designing surveys, conducting experiments (especially in the field), and using models of various kinds to make sense of their data and identify patterns in nature. Scientists' choices about their methods and how they use these to assert their own credibility helps determine what gets to count as knowledge. In my own study of salmon farming science, for example, I found it interesting how scientists developed research techniques that used the unique environmental conditions available at particular field sites to derive conclusions that could also be valid elsewhere. ${ }^{7}$

3) The environmental contexts of scientific activity. Scientists work in many environments: both controlled field sites, and unpredictable landscapes, including those transformed beyond recognition, such as the tar sands or hydroelectric dam sites. Developing reliable results in such places can pose real challenges, particularly when these results are controversial. When the stakes are high, it is always possible for those opposed to their implications to cast doubt on new knowledge. Attention to where science is done can help in understanding how knowledge is affected when the environment being studied is itself transformed, as well as how constructing scientific practices and facts is inseparable from constructing the identity of a place. Arctic science exemplifies these ties 


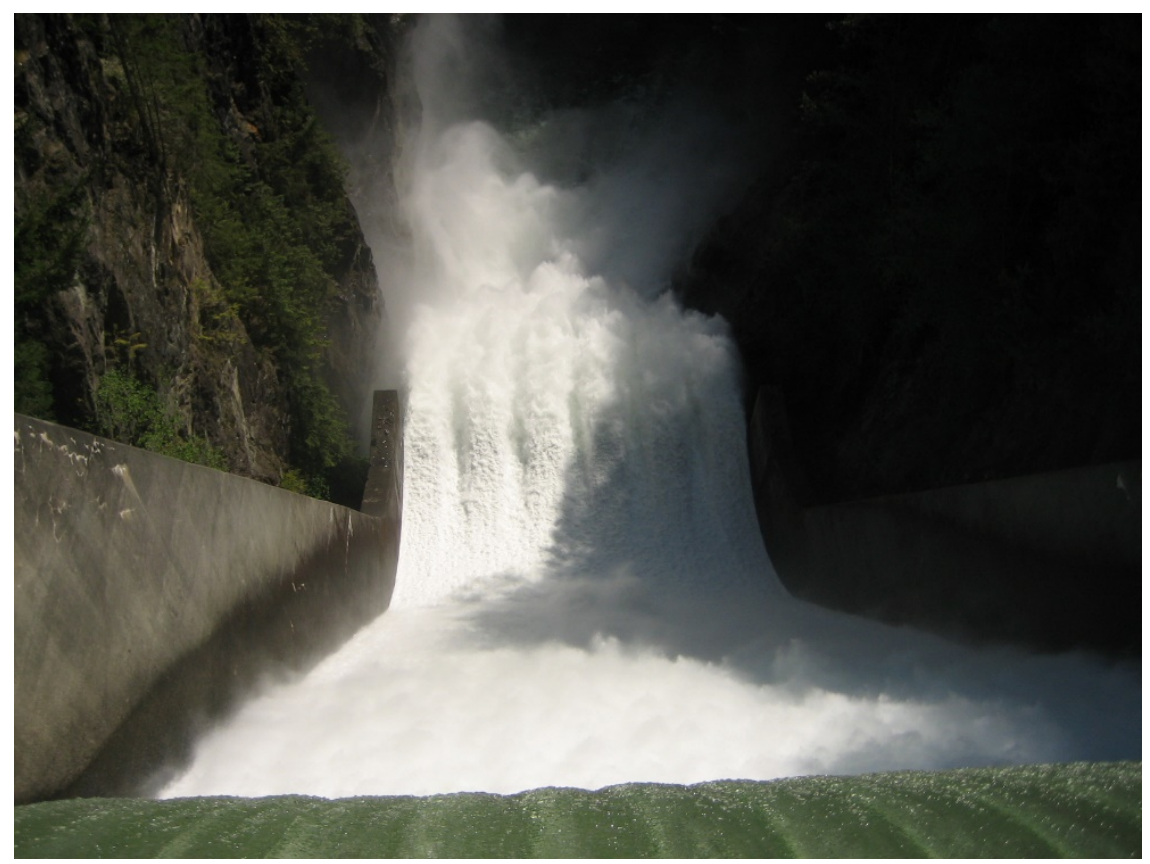

Figure 4. Cleveland Dam, Capilano River, North Vancouver. Photo: Stephen Bocking.

between knowledge and place. In recent decades scientists and Inuit have reframed how we see this region: once forbiddingly cold, now dangerously warm.

4) The historical geography of science. Scientific activity has ebbed and flowed across the Canadian landscape, responding to government and industrial patronage and scientists' priorities. This geography raises many interesting questions, such as the relation between the postwar expansion of science in northern Canada and efforts to administer and exploit the region, the influence of global scientific activities (such as climate change studies) on knowledge of our own environment, and the relation between local knowledge and technical expertise imported from elsewhere. Knowledge can itself be mobile, alongside commodities, people, and power. 
It can even draw power, in fact, from demonstrating the capacity to move, or by asserting ties to a specific place.

5) Indigenous knowledge and its relation to science. Once dismissed by scientists as anecdote and superstition, Indigenous knowledge has more recently been recognized as a source of guidance, of insight into memory and meaning, and as an important basis for asserting territorial and political rights. ${ }^{8}$ But there's also a history of scientists drawing on Indigenous knowledge for their own purposes, often without acknowledging their sources, and of regulatory systems viewing it as merely a source of data. ${ }^{9}$ These and other relations between knowledge systems in Canada deserve more study.

So there's much to pursue in the study of the environmental history of landscapes of science. In the Anthropocene, thinking about environmental knowledge raises essential issues of power, identity, interests, and even human survival. As Christophe Bonneuil and Jean-Baptiste Fressoz have argued recently, knowledge should be at the centre of our understanding of the history of the Anthropocene, because we created this new era fully aware of what we were doing-and we did it anyway. ${ }^{10}$ Understanding how and why knowledge both enabled and warned of planetary transformation represents a pressing agenda for environmental historians ready to engage with the biggest questions of our future.

${ }^{1}$ Nathan Young and Ralph Matthews, The Aquaculture Controversy in Canada: Activism, Policy, and Contested Science (Vancouver: UBC Press, 2010).

${ }^{2}$ Andrew Stuhl, Unfreezing the Arctic: Science, Colonialism, and the Transformation of Inuit Lands (Chicago: University of Chicago Press, 2016) https://doi.org/10.7208/chicago/9780226416786.001.0001. 
${ }^{3}$ L. Anders Sandberg, Gerda R. Wekerle and Liette Gilbert, The Oak Ridges Moraine Battles: Development, Sprawl, and Nature Conservation in the Toronto Region (Toronto: University of Toronto Press, 2013).

${ }^{4}$ Matthew Farish, "Frontier Engineering: From the Globe to the Body in the Cold War Arctic," The Canadian Geographer 50, no. 2 (2006): 177-96, https://doi.org/10.1111/j.0008-3658.2006.00134.x (and subsequent papers by Farish); Stéphane Castonguay, Protection des Cultures, Construction de la Nature: Agriculture, Foresterie et Entomologie au Canada, 1884-1959 (Montreal: Septentrion, 2004); Caroline Desbiens, Power from the North: Territory, Identity, and the Culture of Hydroelectricity in Quebec (Vancouver: UBC Press, 2013); Richard Rajala, Clearcutting the Pacific Rain Forest: Production, Science, and Regulation (Vancouver: UBC Press, 1999).

${ }^{5}$ Christopher Sellers et al., The EPA Under Siege: Trump's Assault in History and Testimony (N.p.: Environmental Data \& Governance Initiative, 2017), https://100days.envirodatagov.org/epa-under-siege/.

${ }^{6}$ See, for example, Paula Stephan, How Economics Shapes Science (Cambridge, MA: Harvard University Press, 2012).

${ }^{7}$ Stephen Bocking, "Science, Salmon, and Sea Lice: Constructing Practice and Place in an Environmental Controversy," Journal of the History of Biology 45, no. 4 (2012): 681-716, https://doi.org/10.1007/s10739-011-9299-z

${ }^{8}$ Emilie Cameron, Far Off Metal River: Inuit Lands, Settler Stories, and the Making of the Contemporary Arctic (Vancouver: UBC Press, 2015).

${ }^{9}$ Paul Nadasdy, Hunters and Bureaucrats: Power, Knowledge, and AboriginalState Relations in the Southwest Yukon (Vancouver: UBC Press, 2003).

${ }^{10}$ Christophe Bonneuil and Jean-Baptiste Fressoz, The Shock of the Anthropocene: The Earth, History and Us (London: Verso, 2016). 


\section{Chapter 2}

The Go Home Bay Biological Station: A Landscape of Science

William Knight

IN THIS VOLUME'S FIRST CHAPTER, Stephen Bocking proposes areas for further research into the environmental history of science in Canada. Among them, he suggests that historians pay closer attention to the historical geography of science, including the situated relations of scientists, governments, and Indigenous peoples. Stephen's original blog post on this subject prompted me to re-examine a particular landscape of science-Canada's first freshwater research laboratory, the Go Home Bay Biological Station in Ontario.

The station was part of the Madawaska Club, a private summer resort established by University of Toronto faculty in 1898. Club members bought 1,600 acres of rocky land and islands around Go Home Bay, an inlet on Lake Huron's Georgian Bay. Members occupied the rugged and isolated site in May of 1898, camping and eating communally. Over time, members built permanent dwellings, and the club (which still exists) became an enclave of private cottages. Club members lived seasonally at Go Home Bay, enjoying community picnics, sailing regattas, and church services through the summer months. ${ }^{1}$

Club members established the biological station in 1901. Two years later they convinced the federal government to fund the laboratory. The second federally supported field station in Canada, the Go Home Bay Biological Station joined a network of American laboratories previously established in Michigan and Ohio. These stations focused attention on Great Lakes fisheries, hoping to better understand their biological 


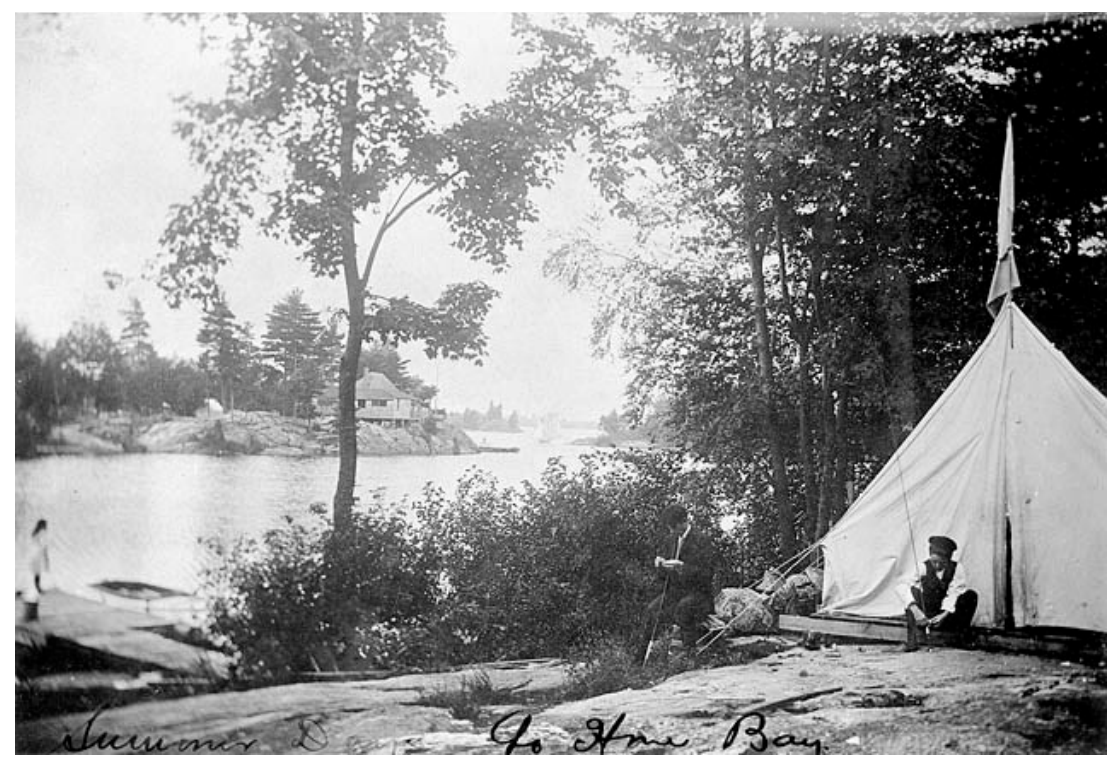

Figure 1. Summer days in Go Home Bay. Photo:J.W. Bald/Library and Archives

Canada/PA-029360.

conditions and thus inform state regulation and fish-culture policy. By 1905, the Go Home Bay station consisted of a lab building, a boathouse, and living quarters for researchers, who often arrived in May and did not leave until September.

That the biological station was embedded in a summer resort was not unusual. Philip J. Pauly and Helen M. Rozwadowski have described "resort science" in the United States and how it fostered professional scientific communities, helping to define biology as a discipline. As Rozwadowski argues, recreation, like work, was a mode of knowing nature. Whether during expeditions or encamped at stations, scientists and students enjoyed vacations while also pursuing their outdoor studies, blurring the line between recreation and research. ${ }^{2}$

What Pauly and Rozwadowski leave unexplored, however, is the historical geography of these resorts. For the Madawaska Club and its 
biological station, the critical context is Georgian Bay's complex history of treaties and land surrenders, the legal terrain that transformed Georgian Bay into a summering place for settlers in the late nineteenth century. This history, detailed by Peggy Blair in Lament for A First Nation, frames the pursuit of science at the station in turn. ${ }^{3}$

As Blair shows, treaty-making in the region confined the region's Ojibway bands, including Chippewa of Lake Simcoe and southern Georgian Bay, to an increasingly smaller land base as conflict with settlers over resources increased. Treaties, however, only vaguely defined critical areas, particularly southern Georgian Bay. To settlers, the 1850 RobinsonHuron Treaty ceded territory from Penetanguishene in southern Georgian Bay to Sault Ste. Marie in the north.

But First Nations did not accept this interpretation. They argued the treaty never covered the Bay's extensive archipelago of islands, channels, and bays. Moreover, Chippewa occupied key islands in Georgian Bay, most notably Manitoulin and Christian islands. The latter became a reserve in 1856, providing a home for Chippewa to continue traditional food provisioning in places such as Go Home Bay.

Through the last half of the nineteenth century, settlers intensified their exploitation of Georgian Bay's minerals, fish, and timber. Facilitated by an expanding transportation network, settlers soon pursued another form of exploitation-tourism. Itinerant tourists were the first to visit, followed by those who sought permanent cottage sites for seasonal occupation. In the late 1890s, there was a land rush of sorts as people from southern Ontario and the northeastern United States bought up islands and shorelines in Georgian Bay. ${ }^{4}$

By the time Madawaska Club members bought Go Home Bay at a "nominal price"-a favorable transaction facilitated by Crown Lands Commissioner J.M. Gibson, a University of Toronto alumnus-the site was an exploited and contested one. Frank Fenton, a former commercial fisher 


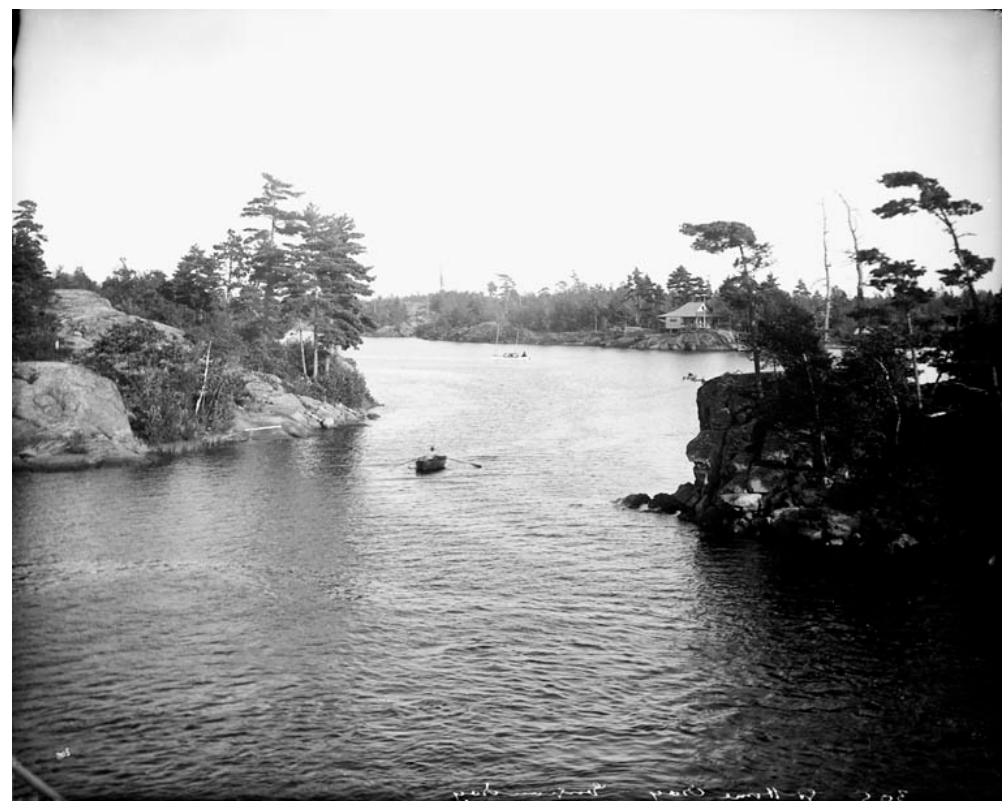

Figure 2. Summer days in Go Home Bay. Photo:J.W. Bald/Library and Archives

Canada/PA-029360.

and the club's caretaker, recalled that commercial fishing operations "had pretty well skinned the pickerel [walleye] out before the Madawaska Club moved in." ${ }^{5}$ The surrounding region had also been logged, though it is not clear if Go Home Bay itself had been cleared.

Despite this sale, Chippewa on Christian Island maintained their land claim and exercised their traditional harvesting rights. Club histories show that Chippewa from the Christian Island band regularly visited Go Home Bay to camp and pick blueberries. The club claimed to tolerate these annual visits, framing them as quaint reminders of a romantic past rather than active resistance to a territorial occupation. "The Indians," the first club history recounts, “...were in general very welcome with their baskets and mats as a picturesque and vivid reminder of a vanished era." 6 
The picturesque Indian became an inconvenient one after club members grew intolerant of these annual visits and the band asserted its members' rights. The Christian Island band told the club that band members "could not be prevented from camping on their accustomed ground." The Madawaska Club then asked the federal Department of Indian Affairs to intervene. In 1915, Deputy Minister Duncan Campbell Scott complied and wrote the Christian Island band, demanding that its members stop visiting Go Home Bay. ${ }^{7}$

Throughout this period, the Madawaska Club continued to expand its enclave. While the club had originally bought the land from the Ontario government in 1898, it later bought land directly from Indian Affairs. Club secretary W.J. Loudon kept close tabs on island sales. In 1906, he was able to buy 76 of them-some of them mere rocks that disappeared when water levels were high-extending the club's privatization of contested territory. ${ }^{8}$

Another important historical-geographical context for the Go Home Bay Biological Station is Georgian Bay's fisheries. The Bay's fishparticularly its lake trout, whitefish, and walleye-supported Indigenous subsistence and, after settlers began encroaching on them, commercial and recreational fisheries that expanded through the last half of the nineteenth century. In 1857, the Fisheries Act legitimized dispossession by allowing settlers to fish, and lease, treaty-protected waters. The Fisheries Act also initiated efforts to privilege sport fisheries with measures such as closed seasons, gear restrictions, and catch limits. ${ }^{9}$

These efforts, which marginalized and criminalized Indigenous fisheries, frame the science undertaken at Go Home Bay. Loudon, the club secretary and charter member who helped secure the station's government funding, wanted the biological station to focus on one fish, the smallmouth bass (Micropterus dolomieu). Classified as a game fish-and one increasingly reserved for sports fishers-bass were a locus for conflict in Georgian Bay, which was by the late 1800s a famed location for bass 
angling. Anglers in the region blamed unrestrained commercial and Indigenous fisheries for declining catches, and demanded that regulations that protected bass be more stringently enforced. ${ }^{10}$

It is noteworthy, then, that the station's first project, according to Loudon, was an experiment in bass fish-culture that involved raising fish in a pond on one cottager's property. It is unclear how long the station pursued this work, but it provided material for Loudon's 1910 book The small-mouthed bass. There, he noted these experiments along with vivid descriptions of his angling experiences; he also articulated demands for more concerted regulation of bass in Georgian Bay. In Loudon's estimation, the station's scientific mission blended seamlessly with the club's recreational preoccupations, and served to further the latter. Loudon claimed that conserving bass as a "profitable resource" would also help preserve Go Home's utility as a "breathing spot... during the hot summer months." ${ }^{11}$

Bass are less obviously an object of study in the collection of papers detailing the station's research, published in 1915 after the station closed. Papers included catalogues of fish, insects and other invertebrates. B.A. Bensley's list of Georgian Bay fish referred, however, to a fish-tagging experiment with bass. Now a common approach to investigating fishpopulation dynamics, mark-and-recapture studies were then innovative and required angler participation to complete. W.A. Clemens, who studied insect life at the station, may have been involved, or at least took note. He later suggested fish-tagging be used to track migrating sockeye salmon in the Fraser River. ${ }^{12}$

Clemens' sojourn at the station illustrates Go Home Bay's role as an incubator of Canadian fisheries science expertise, and sustains Pauly's and 


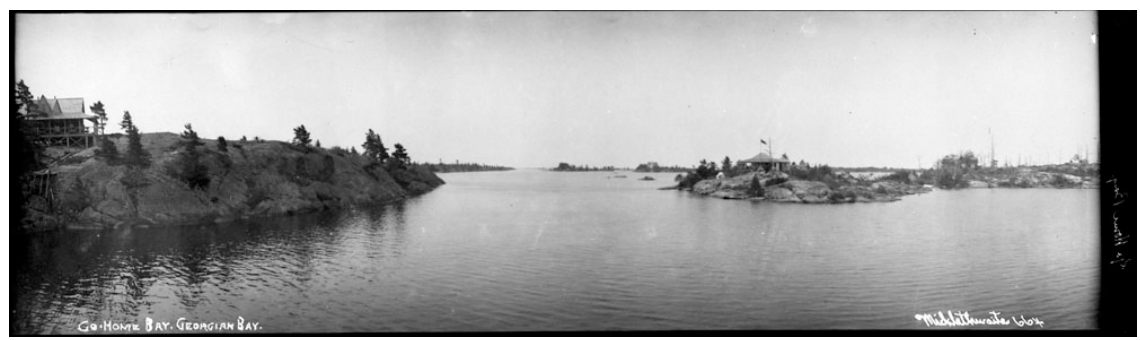

Figure 3. Go Home Bay, Georgian Bay, Ontario. Photo: Frank W. Micklethwaite/Library and Archives Canada/PA-068493.

Rozwadowski's views of the relationship between resort science and the professionalization of biology. Clemens went on to become director of the Pacific Biological Station in Nanaimo, British Columbia, while B.A. Bensley, the station's director for most of its existence, went on to found and direct the Ontario Fisheries Research Laboratory at the University of Toronto. Established in 1921, this laboratory initiated the first provincially directed program of freshwater fisheries science in Canada, as Stephen Bocking has shown elsewhere. ${ }^{13}$

As a site of resort science, the Go Home Bay Biological Station shows how historical-geographical perspectives can deepen our understanding of such places. My interest in Go Home Bay had indeed lain dormant until Stephen's post renewed my interest and encouraged me to look again at this site. Thinking about landscapes of science helps to ground accounts of scientific activity in specific locales, and among specific communities with competing interests and histories. It reminds us that science takes place to happen.

My thanks to Anne Riitta Janhunen for discussion of nineteenth-century land surrenders in Georgian Bay. 
${ }^{1}$ The club's history is outlined in two privately printed books: The Madawaska Club: Go-Home Bay 1898-1923 (Midland, ON: The Midland Press, 1923) and The Madawaska Club: Go-Home Bay 1898-1948(Midland, ON: The Midland Press, 1948). Members originally planned to purchase property where the Madawaska River flowed into Rock Lake, which today lies within Algonquin Park. Opposed by logging companies, they turned to Georgian Bay. The club's name thus retains a trace of their initial plan. See Madawaska Club(1929): 34. ${ }^{2}$ Philip J. Pauly, "Summer Resort and Scientific Discipline: Woods Hole and the Structure of American Biology, 1882-1925," in The American Development of Biology, ed. Ronald Rainger, Keith Benson, and Jane Maienschein (Philadelphia: University of Pennsylvania Press, 1988), 121-50, https://doi.org/10.9783/9781512805789-007; Helen M. Rozwadowski, "Playing By-and On and Under-the Sea: The Importance of Play for Knowing the Ocean," in Knowing Global Environments: New Historical Perspectives on the Field Sciences, ed. Jeremy Vetter (New Brunswick, NJ: Rutgers University Press, 2011), 162-89.

${ }^{3}$ Peggy Blair, Lament for a First Nation: The Williams Treaties of Southern Ontario (Vancouver: UBC Press, 2008).

${ }^{4}$ Claire Elizabeth Campbell, Shaped by the West Wind: Nature and History in Georgian Bay (Vancouver: UBC Press, 2005). For histories of American fishing clubs in the region, see Bob Reigeluth, "Iron City Fishing Club History" and Timothy O. Flora, "Pennsylvania Club History since 1896," http://pennsylvaniaclub.com/history/index.html.

${ }^{5}$ Madawaska Club(1948): 44.

${ }^{6}$ Madawaska Club(1923): 27. Club members attested to the site's productivity: one recalled picking "more than 20 quarts which we shipped in packing cases to our friends at home." Madawaska Club(1948): 18.

${ }^{7}$ J.D. McLean to W.J. Loudon, January 15, 1906, Library and Archives Canada, RG 10, vol. 2860, file 176,296-49.

${ }^{8}$ Madawaska Club(1923): 28. 
${ }^{9}$ Margaret Beattie Bogue, Fishing the Great Lakes: An Environmental History, 1783-1933(Madison, WI: University of Wisconsin Press, 2000), 179.

${ }^{10}$ William Knight, “'Our Sentimental Fisheries': Angling and State Fisheries Administration in $19^{\text {th }}$ Century Ontario" (MA thesis, Trent University, 2006), 9297.

${ }^{11}$ W.J. Loudon, The small-mouthed bass (Toronto: Hunter \& Rose, 1910), 88.

${ }^{12}$ B.A. Bensley, "The Fishes of Georgian Bay," in Contributions to Canadian Biology Being Studies from the Biological Stations of Canada 1911-1914. Fasciculus II-Fresh Water Fish and Lake Biology (Ottawa: King's Printer, 1915), 44.

${ }^{13}$ Matthew Evenden, Fish vs. Power: An Environmental History of the Fraser River (Cambridge: Cambridge University Press, 2004), 50; Stephen Bocking, "Ecology and the Ontario Fisheries," in Ecologists and Environmental Politics: A History of Contemporary Ecology (New Haven, CT: Yale University Press, 1997), 151-78. 


\section{Chapter 3}

Animal Matters: Bovine Smallpox Vaccine at the Connaught

Laboratories and University Farm

Joanna Dean

MANY OF OUR MOST VIRULENT DISEASES have emerged from the fertile intersections of human and other animal bodies. Cures also crossed the species barrier, and in the crossing carried the taint of their animal origins. At the turn of the nineteenth century, antitoxins were extracted from the blood of retired workhorses, and smallpox vaccines were produced from calves in "vaccine farms," where the purity of the product was further compromised by association with the muck of the barnyard. In 1917, when the University of Toronto opened the Connaught Laboratories and University Farm, a new modern facility for the production of serums and vaccines, they faced a nascent antivivisectionist movement from within the ranks of those opposed to vaccines. Photographs disseminated by the Connaught demonstrate the power of the visual image in managing-even erasing-the animal origins of biomedical products through an emphasis on hygiene and health.

As its cumbersome name suggests, the Connaught Laboratories and University Farm was a hybrid landscape of science, neither entirely laboratory nor entirely farm. Press coverage of its official opening drew a distinction between the hygienic, scientific, and modern laboratory (the main building) and the farm (the acreage). The laboratory was linked back to the university, 12 miles to the south in the city: "the Connaught Laboratories of the Department of Hygiene of the University of Toronto." The farm was almost incidental: "with the laboratories is a farm of 50 


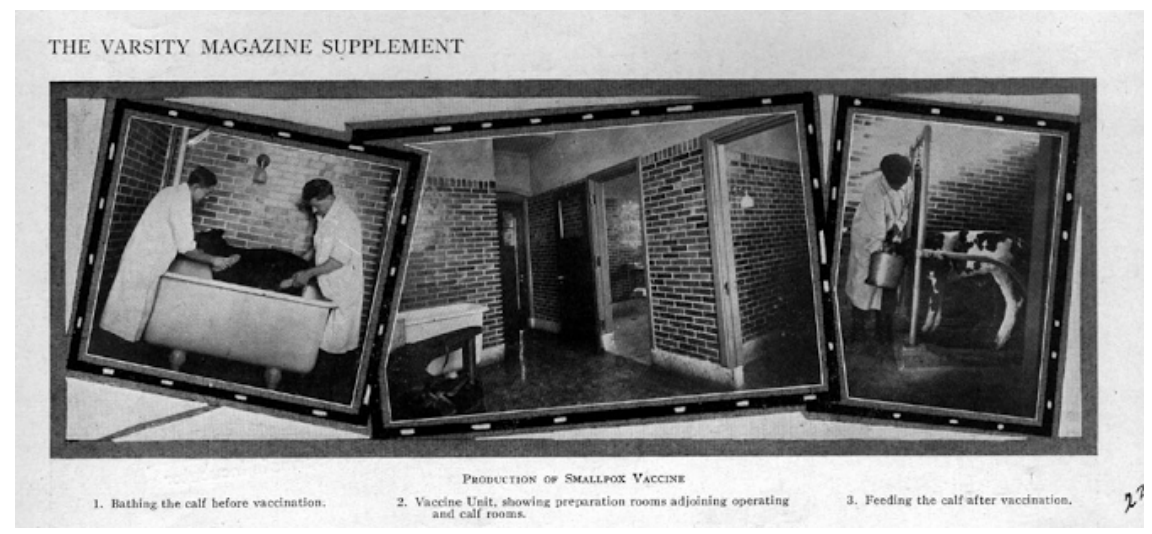

Figure 1. A collage of photographs from the Varsity Magazine Supplement, 1918. Copy in Sanofi Pasteur Canada (Connaught Campus) Archives, Toronto.

acres." ${ }^{1}$ But the distinction between laboratory and farm was difficult to maintain. The production of serums and vaccines necessitated an intimate association with animals. Behind its elegant exterior the Connaught laboratory building was very much a barn, with horse stables and calf stalls dominating the main floor, guinea pig pens and hayloft above, and paddocks behind.

The impetus and financing for the construction of the Connaught came from the wartime demand for tetanus antitoxin, but the laboratory produced a growing number of other biomedical products. This chapter will focus on the most controversial of these: bovine smallpox vaccine. Fear of the vaccine and anger at the compulsory vaccination of children led to protests across Britain and North America. Montreal residents rioted in the streets in 1875 and 1885, and Toronto was torn by debate about the compulsory vaccination of schoolchildren in 1906, and then again in 1919. While most of the anger was aimed at the intervention of the state into the body of the child and the sanctity of the home, the opponents of vaccination also raised concerns about the efficacy and safety of the vaccine and the dubious conditions under which it was produced. Some medical historians have been dismissive of antivaccinationists: Michael Bliss, for example, 
argued that they were simply "wrong." But, as Paul Bator, Katharine Arnup, and Jennifer Keelan have shown, parents had good reason to be suspicious of these early vaccines. ${ }^{2}$ This chapter focuses upon concerns about the animality of the vaccines, a topic that has received very little attention in the literature.

The bovine origins of the vaccine provoked fear and disgust as well as sympathy: fear of crossing the species barrier, disgust at the nature of the vaccine, and sympathy for the suffering of the animal. The vaccine only worked because of the similarity between human and bovine bodies. Because it breached the barrier between the human and the "animal," there were fears that other cow-like characteristics might travel with it. As R.S. Weir, secretary-treasurer of the Canadian Anti-Vaccination League, said in 1903: "The animal product, being chiefly lymph taken from the blood of the brute, has registered in it all the physical qualities of that animal." ${ }^{3}$ In England stories about children with horns had circulated in the early years of vaccine production, and there were lingering fears that the vaccinated child might manifest signs of "the brute."

There was also disgust at the "animal matter" that made up the vaccine material. In 1902, Weir referred to the "rotten pus that has been scraped from the ulcers of a diseased beast," and in 1903 he protested a policy that would "compel every child in the land to be not only wounded, but blood poisoned also, with putrid matter from the festering sores of a diseased beast." ${ }^{4}$ In 1906, Trustee Levee argued before the Toronto Board of Education that children's bodies should not be polluted with "animal matter." The word "matter" is not as widely used today; at that time, it was redolent of pus, putrefaction, and corruption. "Animal matter" was another order of impurity, especially to a public familiar with the filth of stables and barns. The use of the term peaked at the turn of the century. Readers of Toronto newspapers were reassured that products as various as Ostermoor 
mattresses and Stuart's Dyspepsia tablets were free of "animal matter and other impurities... and as safe and harmless for the child as for the parent." Even ordinary soap was suspect. "Laundry soaps are made from dead animals," read a $1915 \mathrm{ad}$, which then assured consumers that "Lawrason's Snowflake Ammonia contains no animal matter." ${ }^{6}$

Trustee Levee had been speaking on a motion to repeal the bylaw for the compulsory vaccination of schoolchildren. He wielded a petition between 5,000 and 10,000 signatures strong: the number varies with the source, but even the lower number was extraordinary for a city the size of Toronto. His motion passed, with only one trustee speaking against it. ${ }^{7}$ The Toronto Star called on the medical profession to combat the rhetoric of antivaccination groups with "facts and arguments." A.B. Macallum, a professor of biochemistry and physiology at the University of Toronto, obliged. But his outraged letter, sent to both the Toronto Star and The Globe, made the mistake of repeating and amplifying Levee's rhetoric, referring to "filthy animal matter." 8

The problem lay in the fact that the term "animal matter" was not entirely incorrect. Bovine smallpox vaccine was lymph taken from the pustules of calves infected with cowpox. The use of the calf was an improvement over earlier methods that had involved the transfer of lymph from one human arm to another. A calf could not transmit human diseases such as syphilis as human fluids might. To produce bovine vaccine, the calf was shaved and scarified with vaccine; five days later large vesicles formed, and when the vesicles were considered ripe they were broken and the lymph harvested. It was this material that was used to vaccinate children against smallpox.

Medical authorities attributed problems with the vaccines to poorly regulated vaccine farms. In 1902, the Canadian Journal of Medicine and Surgeryopined that biomedical products such as virus and serum could not be produced from "worn-out horses and sickly calves" in "dirty stables or 
improvised annexes to vermin infested barns.” They argued that these products should be manufactured in hygienic conditions: "Healthy animals, perfect plants constructed and managed under expert supervision, and the assurance of pure cultures with entire freedom from pus organisms are the essential conditions." ${ }^{9}$ Public health officials quietly mobilized to overcome popular opposition to vaccination. In 1914, the province of Ontario passed the Vaccination Act, which enabled mandatory vaccination in case of a smallpox outbreak and empowered medical officers of health to require vaccination certificates of all pupils. The University of Toronto answered the call for healthy animals and "perfect plants" by taking over vaccine production from the disreputable Ontario Vaccine Farm and setting aside one corner of the new Connaught laboratory as a vaccine unit. They launched public relations campaigns to convince Toronto parents of the purity of their vaccine, the hygiene of their laboratory, and the well-being of their calves. ${ }^{10}$

Robert Defries, the associate director of the Connaught Laboratories, addressed the concerns of the Canadian Anti-Vaccination League in an article in the University of Toronto's 1918 Varsity Magazine Supplement. Defries took care to distinguish his facility from ordinary farms: it was an "ideal" farm, with "the most modern antitoxin stable and laboratories." He explained that the production of vaccines "necessitates exacting care in the development of vaccine from healthy calves, and requires most modern equipment."11 A collage of three photographs, titled "Production of Smallpox Vaccine," took on the real work of reassuring the public about the process (Figure 1). The first image, "Bathing a calf before vaccination," depicts a calf being washed in a large white enamel bath by two whitecoated technicians in a spotless room. A second photograph, "Vaccine Unit" (enlarged in Figure 2), further emphasizes the gleaming walls of glazed brick and - again - the white enamel bath. In this photograph, the most 


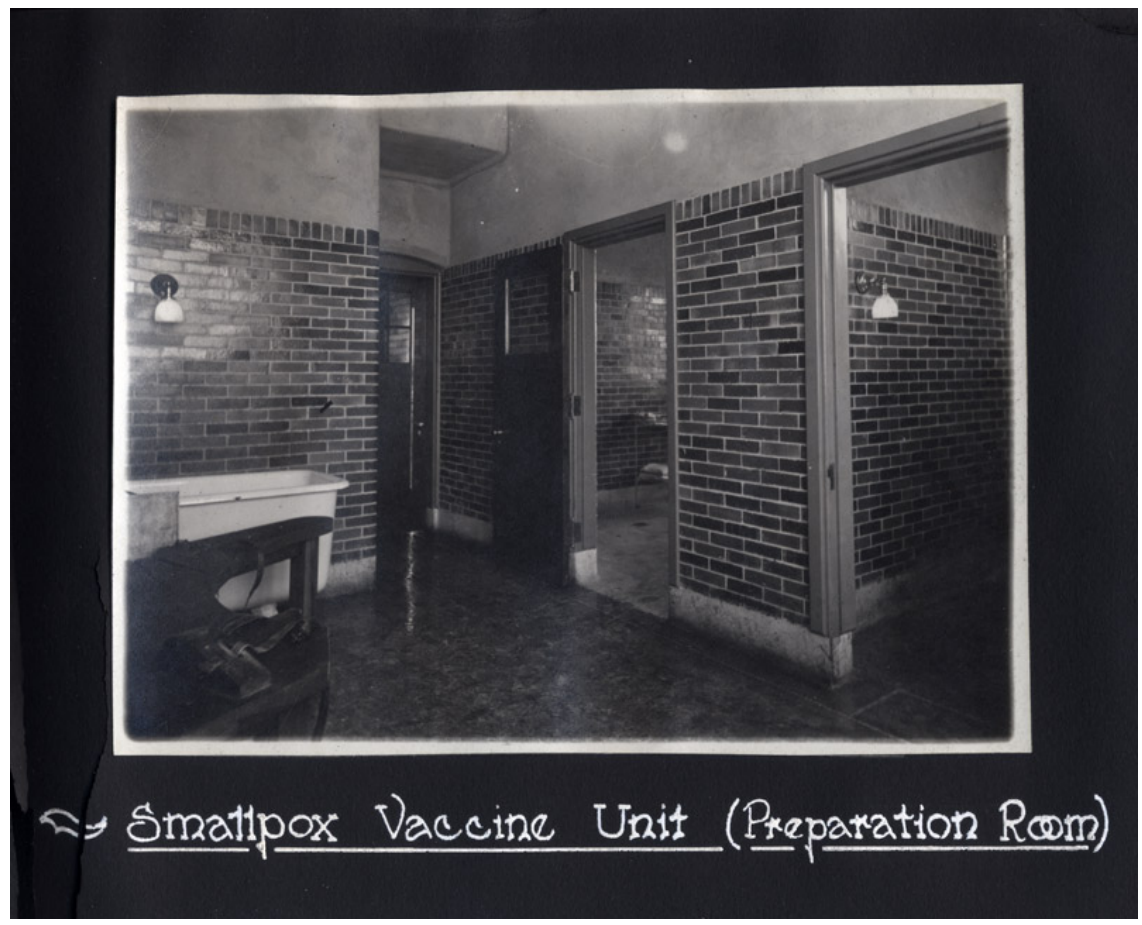

Figure 2. Smallpox Vaccine Unit (Preparation Room). 1918 Photograph Album, Sanofi Pasteur Canada (Connaught Campus) Archives, Toronto.

central and the largest in the collage, the animal itself disappears from view. A third photograph, "Feeding the calf after vaccination," shows another white-coated technician, with a healthy (and clean) calf eating from a large bucket.

The photographs speak of hygiene, most obviously with the bath, but more subtly through light reflecting on glazed brick walls and tiled floors. Glazed brick is not a sign of hygiene today, and these photographs are best read in conjunction with a story about the laboratory's construction published in the industry journal, The Contract Record. The author takes care to explain the need for the animals' presence: "The building must include housing accommodation for animals, as well as purely laboratory arrangements." The "efforts made to secure sanitary conditions" were then 
described in detail: "The walls in the stables and laboratory rooms are lined with the glazed brick dado, which can easily be kept clean. All internal angles are coved to avoid dust catching conditions and all corners are bull nosed." 12 A photograph of the immaculate stable, with gleaming tiled floor and horses almost out of sight, is positioned in the middle of the page.

This photograph was provided by the Connaught. It is one of a set of images of contented animals, clean laboratories, and lab-coated technicians that circulate through photograph albums, photographic collages, and lantern slide shows in the Connaught archives. Photographs made hygiene visible. Unlike text, which was filtered through the subjectivity of the author, a photograph had a kind of veracity: it offered itself up for independent scrutiny as a record of objective reality. Photographs also packed an emotional punch. In 1906, when the Canadian Anti-Vaccination League showed illuminated illustrations at a rally, a journalist noted that a number of people had to leave: "The cases shown were appalling, and no one could resist them as an argument against compulsory vaccination." ${ }^{13} \mathrm{~A}$ war of images ensued: in competing pamphlets, the Provincial Board of Health depicted the horrors of smallpox, which the League countered with images of a botched vaccination. ${ }^{14}$

The aesthetics of the Connaught photographs also mattered. With the exception of a few awkward photographs of antitoxin horses taken before the laboratory was opened, the images the Connaught circulated were sharply focused, symmetrical, and visually appealing. ${ }^{15}$ Arthur S. Goss, the city photographer who documented the benefits of Toronto's growing public health bureaucracy, was an artist who travelled with the Group of Seven. His photographs, like those taken at the Connaught, were beautiful. Goss may have had a hand in the Connaught's public relations campaigns. Either way, his photographs provided the context of hygienic scientific modernity in which the Connaught images were interpreted. 


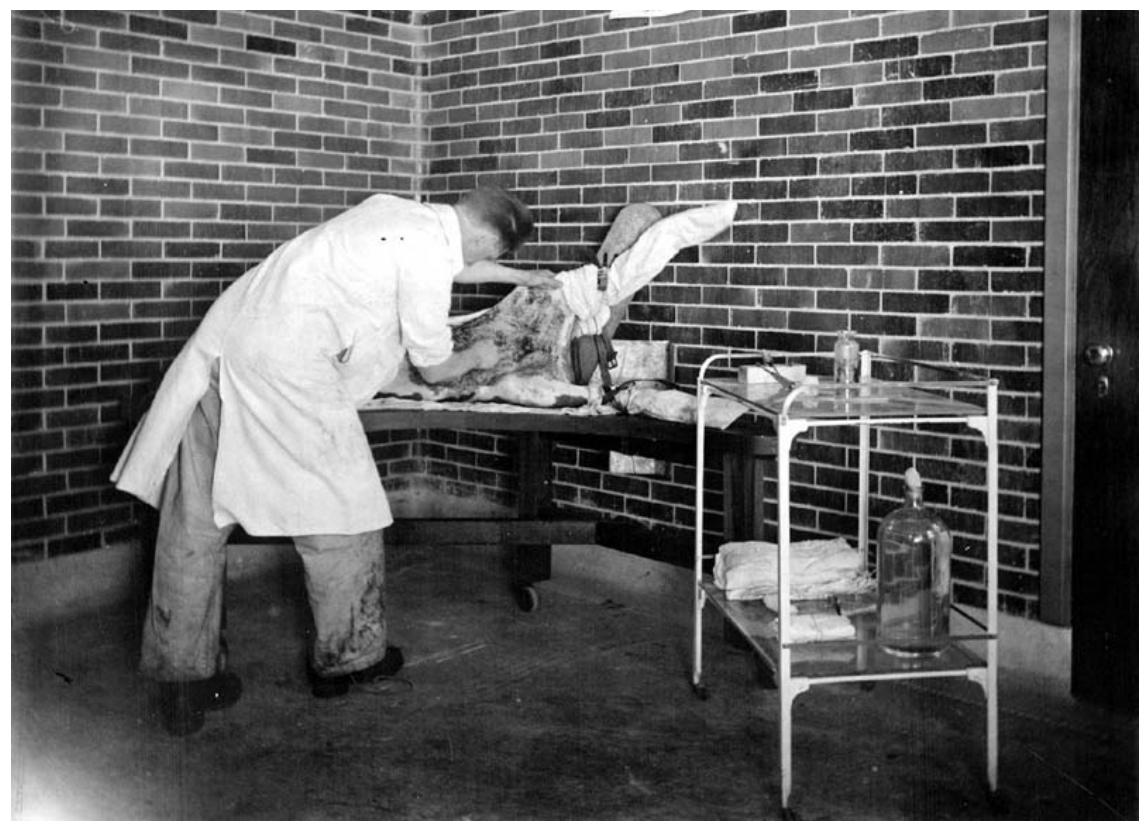

Figure 3. Photograph acc1125, Sanofi Pasteur Canada (Connaught Campus) Archives,

Toronto.

It was not just hygiene that was at stake in the Connaught collage. The photographs also assured readers of the well-being of the calf: they demonstrated that he was bathed (in an enamel tub, much as one might bathe a child) and well fed. The Connaught archives show that at least five photographs were taken of vaccine production, but only three appear in the Varsity Magazine Supplement. Two were omitted. The first of the absent photographs shows a calf splayed on the operating table, legs encased in white cotton, with a technician scraping the vesicles, next to a glass-topped laboratory table (Figure 3). The technician is white-coated, but dark smears of what appears to be blood can be seen on his trousers. The Supplement also excluded a second photograph in which the empty operating table is central and leather restraints hang to the floor (Figure 4). ${ }^{16}$ As Timothy Pachirat has observed, the politics of sight consist of that which is hidden from view, as well as that which is seen. ${ }^{17}$ These absent images-the 


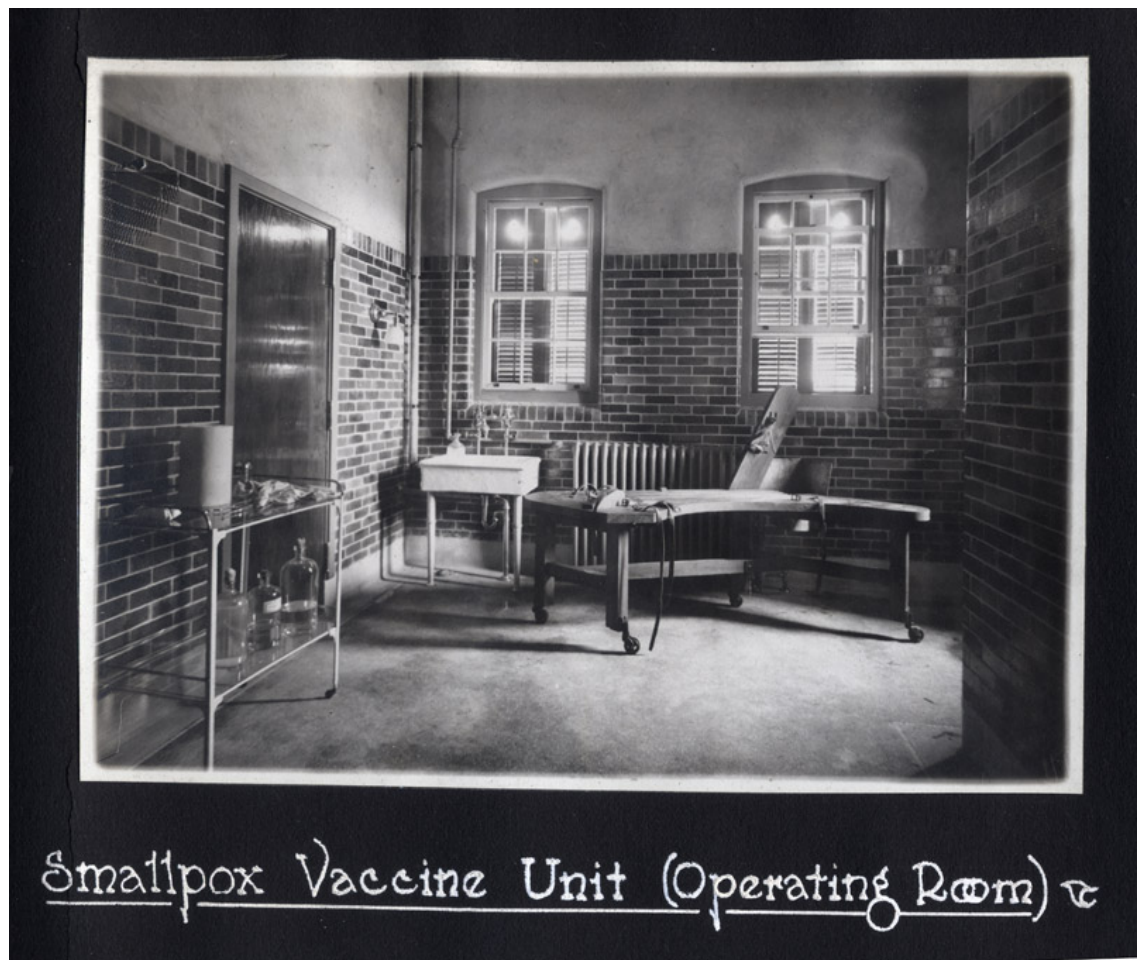

Figure 4. Smallpox Vaccine Unit (Operating Room). 1918 Photograph Album, Sanofi Pasteur Canada (Connaught Campus) Archives, Toronto.

photograph of an animal under the knife of the lab-coated scientist and the photograph of the laboratory restraints-point to the second context in which the Connaught images operated: that of Canada's nascent antivivisectionist movement.

Canada had no antivivisectionist organization in 1918, but antivivisectionist speakers occasionally appeared at the Toronto Humane Society's meetings, and Canadians were familiar with the arguments of British and American activists. ${ }^{18}$ Historians have described a resurgence of antivivisection sentiment in the United States and Britain after the First World War that arose out of the movement against compulsory vaccination. It appears that a similar trajectory took place in Canada. ${ }^{19}$ The 
broad and diverse antivaccinationist movement provided a natural home for antivivisectionists. Both movements had long been opposed to the emerging power of laboratory medicine, and as the number of animals used for the production of biomedical products increased, both focused upon the same landscape of science. The Globe reported that, of 35,512 vivisection experiments in Britain in 1917, 22,000 were for the preparation, testing and standardizing of sera, vaccines, and drugs. ${ }^{20}$ The two movements found common cause during the First World War when Walter Hadwen, the president of the powerful British Union for the Abolition of Vivisection and a man who had himself been recruited from the ranks of antivaccinationists, campaigned against the compulsory vaccination of soldiers.

Hadwen spoke frequently in Canada. He was described in The Globe as an eminent physician and surgeon, "one of the greatest exponents and lecturers on the subject of serums, anti toxins, vaccines and inoculations that we have on either side on the Atlantic." ${ }^{21}$ An article of his published in the Ottawa Citizen in 1918 provides some insight into his thoughts on animal matter(s), and demonstrates the ways in which antivivisectionism and antivaccinationism intersected. He shared the antivaccinationists' disgust with lymph, describing the vaccine as a "conglomeration of filth," but his article focused on the mistreatment of animals rather than the question of hygiene. He described vaccination as "the cruel process consisting of raising numerous sores by artificial means on the abdomen of the calf," decried the "lack of sympathy with the sufferings of speechless and inoffensive creatures," and called for "justice for the brute creation." Then he turned to the implications for people: experimentation on the calf, he said, was "the precursor of modern experimentation on human beings." 22

The Citizen republished Hadwen's article in 1919, just as (and probably because) antivaccination debates resurfaced in Toronto. ${ }^{23}$ In the face of a 
smallpox outbreak, Dr. Charles Hastings, Toronto's medical officer of health, drew upon the new powers conferred upon him by the 1914 Vaccination Act to order the general vaccination of the city's population. When public protests led Toronto's mayor and city council to oppose this action, Hastings ordered the mandatory vaccination of all schoolchildren. He reassured the public that the Connaught vaccines were "absolutely pure." Problems arose, he said, when doctors in regular practice used vaccines from other sources. ${ }^{24}$ This time the order stuck: pupils without a vaccination certificate were sent home in the winters of 1919 and 1920.

The Canadian Anti-Vivisection Society emerged from this moment. The Anti-Vaccination League of Canada was replaced in 1921 by two bodies: the Medical Liberty League and the Canadian Anti-Vivisection Society. ${ }^{25}$ The new Anti-Vivisection Society had strong ties to the Toronto Humane Society, the Theosophical Society, international antivivisection organizations, and the antivaccination movement. Its membership included prominent reformers such as the cartoonist J.W. Bengough; Agnes Stanley, the sister of the late theosophist Flora MacDonald Denison; and Dr. John Fraser, a leading antivaccinationist and author of the pamphlet Flaying the Germ Theory (1918). Bengough had earlier provided cartoons of abused horses for the Toronto Humane Society. At the first public meeting of the Canadian Anti-Vivisection Society, he exhibited drawings of "some of the cruel and useless experiments on animals by vivisectors." 26 Similar antivivisection groups soon emerged in Montreal, Ottawa, Winnipeg, Calgary, Victoria, and Vancouver. ${ }^{27}$

Newspaper articles show that it took some time for the Canadian AntiVivisection Society to disentangle itself from the vaccination issue. ${ }^{28}$ Bengough tried to redirect their focus. He argued at the first public meeting: "[The antivivisection] society was not concerned so much with the treatment of animals for the production of serums, but was opposed to 
experiments by dissection made out of curiosity to prove generally accepted theories." ${ }^{29}$ But the issue would not go away. It almost derailed attempts to create an antivivisectionist group in Montreal in 1922. As an annoyed journalist reported:

The majority of those in attendance were women and several of them made bitter speeches against vaccination, or the use of any serum for the prevention of smallpox or any other disease, denouncing this practice as inhuman to the animals from whom the serums are taken, and a source of danger to those who were subjected to such treatment. ${ }^{30}$

Stanley, the first president of the Canadian Anti-Vivisection Society, and Fraser, the second, continued to raise the issue of vaccination. ${ }^{31}$ It didn't help that Hadwen toured Montreal, Toronto, and Vancouver in 1922, linking vaccination and vivisection explicitly in his lectures. ${ }^{32}$ As late as 1928, a letter to the editor of The Globe opposing the vaccination of children argued that "the Connaught kills calves." ${ }^{33}$

In light of these developments, the Connaught's decision in 1918 not to publish images of the splayed calf and empty restraints was a wise one. Animal advocates were sophisticated in their use of visual imagery, as Keri Cronin has shown, and antivivisectors had long drawn upon medical journals and laboratory manuals for a dark set of images depicting the cruelties of laboratory science. ${ }^{34}$ These two photographs from the Connaught would have resonated with these kinds of earlier images, and would have provided visual ammunition for the nascent Canadian antivivisectionist movement.

Over time, the laboratory animal disappeared from view. The uses to which animals were put in the 1920s did not lend themselves to news stories as easily as clean calves and kind antitoxin horses. The Connaught 
drew less attention to the animals in its care even as the numbers of those animals and the range of species increased exponentially. Even the name of the facility shifted subtly. News articles came to refer only to the Connaught Laboratory; references to the farm disappeared. By 1943, as Liza Piper notes in her chapter in this volume, the word "farm" was officially dropped. ${ }^{35}$ The term resurfaced briefly in 1958 when one of the "men handling monkeys at the farm just north of Toronto" was bitten. For a moment, the facility was once again the "Connaught Laboratories research farm." ${ }^{36}$ But the trend was toward depicting this landscape of science as a modern, scientific laboratory, rather than a vermin-infested farm. The animal became almost, but not quite, incidental.

Thanks to Chris Rutty, archivist at the Connaught Campus, Sanofi Pasteur Canada, Toronto, for his assistance. All errors are my own.

${ }^{1}$ Three news clippings in the Connaught's archives used identical or very similar language to describe the laboratories, suggesting that the wording was provided by the university: "Promote Health of the Soldier" [the newspaper and exact date are unknown, as only the heading "Toronto Friday October" is visible in the clipping]; "The New Connaught Laboratories," Canadian Journal of Medicine and Surgery [handwritten notation "December 1917"]: 153; and "Splendid Gift to University," Mail and Empire, October 26, 1917. Copies of these clippings are located in Sanofi Pasteur Canada (Connaught Campus) Archives, Toronto. An article in The Contract Record similarly distanced the farm from the building: "A fifty acre farm, in connection with the laboratory buildings." The Contract Record, October 24, 1917, 881-82. By comparison, one day before the facility's opening, a news story in the Star emphasized the farm through the use of the title “Toronto University's Experimental Farm.” Toronto Star, October 25, 1917.

Signage on the laboratory building also tied it back to the university in the city. 
See the 1918 photograph album, CAL-1918 album B3-4, Sanofi Pasteur Canada (Connaught Campus) Archives, Toronto.

${ }^{2}$ Michael Bliss, Plague: A Story of Smallpox in Montreal(Toronto:

HarperCollins, 1991), 212. See also Martin Kaufman's dismissive account of American antivaccination movements: "The American Anti-Vaccinationists and Their Arguments," Bulletin of the History of Medicine 41, no. 5 (1967): 463-78. For a more sympathetic analysis, see Paul Adolphus Bator, “The Health Reformers versus the Common Canadian: The Controversy Over Compulsory Vaccination against Smallpox in Toronto and Ontario, 1900-1920," Ontario History 75, no. 4 (1983): 348-73; Katherine Arnup, "Victims of Vaccination?: Opposition to Compulsory Immunization in Ontario, 1900-1990," Canadian Bulletin of Medical History 9, no. 2 (1992): 159-76, https://doi.org/10.3138/cbmh.9.2.159; and Jennifer Keelan, “The Canadian AntiVaccination Leagues, 1872-1892” (PhD diss., University of Toronto, 2004). For Britain, see Nadja Durbach, Bodily Matters: The Anti-Vaccination Movement in England, 1853-1907(Durham, NC: Duke University Press, 2005) https://doi.org/10.1215/9780822386506. For the United States, see James Colgrove, “Science in a Democracy': The Contested Status of Vaccination in the Progressive Era and the 1920s," Isis 96, no. 2 (2005): 167-91, https://doi.org/10.1086/431531; and Jeannette Vaught, "Materia Medica: Technology, Vaccination, and Antivivisection in Jazz Age Philadelphia,” American Quarterly 65, no. 3 (2013): 575-94, 769,

https://doi.org/10.1353/aq.2013.0037.

3 “The Vaccination Question,” The Globe, May 30, 1903. Dr. Alexander M. Ross had formed the Toronto Anti Compulsory Vaccination League in 1888, and had earlier written articles in response to the situation in Montreal. The Canadian Anti-Vaccination League was formed in 1900. Both groups were modelled on similar British organizations. See Bator, “The Health Reformers” and Arnup, "Victims of Vaccination?"

${ }^{4}$ R.S. Weir, “Compulsory Vaccination,” Toronto Daily Star, January 9, 1902; R.S. Weir, "Letter to Editor," The Globe, November 11, 1904. 
5 "A War on Vaccination in the Public Schools: Petition to Abolish the Compulsion has been Signed by 10,000 Citizens, Trustees Favour the Repeal of the By-Law,” Toronto Daily Star, February 28, 1906. The Toronto School Board had previously made vaccination compulsory for pupils in 1894. See Paul Adolphus Bator, "Saving Lives on a Wholesale Plan: Public Health Reform in the City of Toronto, 1900-1930” (PhD diss., University of Toronto, 1979), 22. ${ }^{6}$ Ads for Stuart's Dyspepsia tablets appeared frequently in Canadian newspapers. See, for example, Toronto Daily Star, December 12, 1898; December 14, 1898; December 16, 1898; March 7, 1900; May 21, 1900; February 10, 1902; March 5, 1902; March 7, 1902; and September 25, 1915. For mattresses, see Toronto Daily Star, October 3, 1900; November 27, 1900; and October 28, 1901. For Lawrason's Snowflake Ammonia, see Toronto Daily Star, September 25, 1915. 7 "A War on Vaccination in the Public Schools." The headline of this article claims there were 10,000 signatures. Bator, "The Health Reformers," and Arnup, "Victims of Vaccination?" say there were 5,000 signatures. Both cite "Vaccination Optional Now,” Toronto Daily Star, March 2, 1906.

8 “'Anti-vaccination Craze.' Prof. Macallum thus describes the present agitation,” The Globe, March 7, 1906; "Vaccine is the Remedy. Sharp Letter from Prof. Macallum in Reply to Criticisms," Toronto Daily Star, March 12, 1906. Macallum claimed in his letter that an antivaccinationist had said that the petition contained only 1,000 signatures.

${ }^{9}$ W.R. Inge Dalton, M.D., "Responsibility for the Recent Deaths from the Use of Impure Antitoxins and Vaccine Virus," Canadian Journal of Medicine and Surgery 11, no. 1 (January 1902): 36. Dalton was quoting an editorial from the November 18, 1901 edition of the New York Times.

${ }^{10}$ For background on vaccine farms, see W.B. Spaulding, "The Ontario Vaccine Farm, 1885-1916," Canadian Bulletin of Medical History6, no. 1 (1989): 45-56, https://doi.org/10.3138/cbmh.6.1.45; and Pierrick Malissard, “Pharming' à l'ancienne: les fermes vaccinales canadiennes," Canadian Historical Review 85 , no. 1 (2004): 35-62, https://doi.org/10.3138/chr.85.1.35. 
11 "Connaught and Antitoxin Laboratories, University of Toronto," The Varsity Magazine Supplement, 1918, copy in Sanofi Pasteur Canada (Connaught Campus) Archives, Toronto. The article is focused on the production of tetanus antitoxin. See Joanna Dean, "Species at Risk: C. Tetani, the Horse and the Human," in Animal Metropolis: Histories of Human-Animal Relations in Urban Canada, ed. Joanna Dean, Darcy Ingram, and Christabelle Sethna (Calgary: University of Calgary Press, 2016), 155-88, https://doi.org/10.2307/j.ctv6gqv8c.12.

${ }^{12}$ The Contract Record, October 24, 1917, 882.

${ }^{13}$ Bator, "The Health Reformers," 355, citing Toronto World, March 14, 1906. It is likely that the "illuminated illustrations" were lantern slides, a popular visual genre at this time. The Toronto Humane Society maintained a library of lantern slides on animal welfare issues, and the Connaught created a lantern slide show on antitoxins.

${ }^{14}$ See Bator, “The Health Reformers," 354. He cites Vaccination in Canada: A Reply to Pamphlet Published by the Provincial Board of Health, Ontario (Toronto: Anti Vaccination League of Canada, 1907).

${ }^{15}$ Guests at the Connaught's opening in 1917 were entertained with two reels of motion pictures showing work done in the laboratories. See "Duke Departs After Spending Busy Day: Opens New College Farm and Attends Banquet and University Lecture," Toronto Daily Star, October 26, 1917.

${ }^{16}$ Both photographs can be seen in the 1918 photograph album in the Sanofi Pasteur Canada (Connaught Campus) Archives, Toronto. Electronic copies are labelled CAL-1918 album-B3-4, Smallpox 1 and Smallpox 2.

${ }^{17}$ Timothy Pachirat, Every Twelve Seconds: Industrialized Slaughter and the Politics of Sight (New Haven, CT: Yale University Press, 2012).

${ }^{18}$ Darcy Ingram has shown that deliberate efforts were made to keep women, who made up the majority of antivivisectionists, out of the leadership of animal welfare movements in Canada. See Darcy Ingram, "Wild Things: Taming Canada's Animal Welfare Movement," in Animal Metropolis, 87-113, https://doi.org/10.2307/j.ctv6gqv8c.9. See also his "Beastly Measures: Animal Welfare, Civil Society, and State Policy in Victorian Canada," Journal of Canadian 
Studies 47, no. 1 (2013): 221-52, https://doi.org/10.3138/jcs.47.1.221. Ingram notes that the Toronto Humane Society was, on occasion, willing to broach more controversial issues such as vivisection.

${ }^{19}$ For the United States, see Karen D. Ross, "Recruiting 'Friends of Medical Progress': Evolving Tactics in the Defense of Animal Experimentation, 1910s and 1920s," Journal of the History of Medicine and Allied Sciences 70, no. 3 (2015): 365-93, https://doi.org/10.1093/jhmas/jru018; Susan E. Lederer, "Political Animals: The Shaping of Biomedical Research Literature in Twentieth-Century America," Isis 83, no. 1 (1992): 61-79, https://doi.org/10.1086/356025; and Colgrove, "Science in a Democracy."' Kaufman also notes that the antivivisection movements were reported to have included many antivaccinationists. See Kaufman, "The American Anti-Vaccinationists," 470. For Britain, see Richard D. French, Antivivisection and Medical Science in Victorian Society (Princeton, NJ: Princeton University Press, 1975). For Canada, see J.T.H. Connor, "Cruel Knives? Vivisection and Biomedical Research in Victorian English Canada," Canadian Bulletin of Medical History 14, no. 1 (1997): 37-64, https://doi.org/10.3138/cbmh.14.1.37. Forty years ago, French called for more research into the links between the two groups. However, scholars continue to consider them in isolation, and references to their intersections remain perfunctory. Bator, for example, describes the Canadian Anti-Vivisection Society as an "apparent offshoot" of the Anti-Vaccination League in "The Health Reformers," 354, without referring to any sources. More research is needed to fully understand the relationship between the movements.

Very little has been written on the history of antivivisection in Canada. See Robert Edward McMillan, "The Conflict Over Animal Experimentation in Vancouver, 1950-1990" (MA thesis, University of British Columbia, 2004). See note 26 below for the relationship between the founders of the Canadian AntiVivisection Society and the Toronto Humane Society. 20 "Vivisection Experiments," The Globe, October 18, 1918. 
21 "Cruel, Brutal, Says Lecturer of Vivisection: Dr. Walter H. Hadwen, Noted English Surgeon, Attacks Practice, Claims Public Misled," The Globe, September 25, 1922; "Parrying Blows in Radical Battle," The Globe, September 23, 1922. 22 "Concerning the Alleged Dangers of Vivisection," Ottawa Citizen, August 23, 1918. For a discussion of widespread fears that experimentation on animals would lead to experimentation on humans, see Ian Miller, "Necessary Torture? Vivisection, Suffragette Force-Feeding, and Responses to Scientific Medicine in Britain c. 1870-1920," Journal of the History of Medicine and Allied Sciences 64, no. 3 (2009): 333-72, https://doi.org/10.1093/jhmas/jrp008.

23 "Concerning the Dangers of Vaccination," Ottawa Citizen, March 26, 1919. 24 "M.O.H. States his Faith in Vaccine Treatment," Toronto Daily Star, December 10, 1919. My description of these events is drawn from Arnup, "Victims of Vaccination?”

${ }^{25}$ The Medical Liberty League was also referred to as the Antivaccination and Medical Liberty League. The American Medical Liberty League, formed in 1918, opposed vaccination, medical licensure, isolation of contagious diseases, pure food and drug laws, the testing of cattle with tuberculin, and a host of other public health programs. See Kaufman, "The American Anti-Vaccinationists," 466. ${ }^{26}$ Details of the Society's founding meeting on July 4, 1921 were published in The Canadian Theosophist, September 15, 1921, 106. The article identifies the founding members and describes the Society's connections to the Toronto Humane Society: "Mrs. Mackay has long been associated with the Toronto Humane Society and has always intended to start an anti-vivisection society here. Mrs. Stanley is a sister of the late Mrs. Flora Macdonald Denison, and it appears that Mrs. Denison had also intended starting this work in Canada, so her sister takes up the work for her on her own account." Stanley had become associated with the American antivivisectionist movement while living in Washington for a year. See her photograph and cutline in the Toronto Daily Star, July 4, 1921. A Mrs. Bennett, the mother of Mrs. Allan, a founding member of the Society, had also spoken to the Toronto Humane Society about antivivisection. Finally, Bengough had earlier assisted the Toronto Humane Society with a cartoon targeting those who used the check rein with horses at the 1898 Toronto 
Industrial Exhibition. See Keri J. Cronin, Art for Animals: Visual Culture and Animal Advocacy, 1870-1914(University Park, PA: Pennsylvania State University Press, 2018), location 3010. Bengough became the Society’s third vicepresident in 1923.

Other participants in the Society's founding meeting included Mr. McCausland; Miss Winterbottom; Merrill Denison, Flora Macdonald Denison's son; Mr. J. Van Eden (who became secretary-treasurer); and Miss Lilian Wisdom. Forty members attended the Society's first public meeting in August. For attendance at subsequent meetings, see, for example, "Anti-Vivisection Society Holds Its Annual Meeting,” The Globe, February 1, 1923.

${ }^{27}$ Reference to the formation of a Victoria group, The Humane Education and Antivivisection Society in Canada, can be found in The Canadian Theosophist, November 15, 1921, 139. The fact that this was included in an item about Agnes Stanley suggests a linkage to the Canadian Anti-Vivisection Society, although the name of the Victoria organization differs slightly. Dora Kitto was secretary of the Victoria group. D. Kitto is described as speaking for the SPCA and Western Canada Anti-Vivisection Society in Victoria in The Canadian Theosophist, December 15, 1921, 155. In "The Conflict Over Animal Experimentation” McMillan says that a British Columbia chapter was founded in the 1920s, and that it was also known as the Humane Education and AntiVivisection Society. It then became known as the Anti-Vivisection Society of British Columbia in 1930, was inactive between 1933 and 1940, and returned in 1946 as the Animal Defence and Anti-Vivisection Society of British Columbia. For the Ottawa group (and its antivaccination position), see "Wants to Debate It," Ottawa Citizen, March 24, 1924.

${ }^{28}$ See Bator, “The Health Reformers,” 353-54, for a description of Fraser's antivaccinationist work. Fraser is described in The Canadian Theosophist, September 15, 1921, 106 as having published an article, "Do Germs Cause Disease?" in the May 1919 issue of Physical Culture Magazine. Fraser was elected second vice-president of the Canadian Anti-Vivisection Society in 1923, and president in 1925. See “Anti-Vivisection Society Holds Its Annual Meeting.” 
Kaufman argues for the United States that "the societies generally took no stand on vaccination." See Kaufman, "The American Anti-Vaccinationists," 470. Ross, on the other hand, notes that the leading American antivivisectionists continued to speak on germ theory and vaccination: "As late as 1921, the President of the American Anti-Vivisection Society of Philadelphia remained unconvinced that the germ theory was anything more than a recent fad in a long line of temporarily popular medical theories: "The physical harm being done to our race by the serums, vaccines and anti-toxins evolved from its erroneous theories and unclean practices is surpassed only by the moral destruction wrought by the doctrine that man may do evil that good may come." Ross, "Recruiting 'Friends of Medical Progress," 370.

29 "Demand Probe of Vivisection," The Globe, November 16, 1921. 30 "Anti-Vivisection League Started," The Gazette, April 22, 1922. Subsequent items suggest that this overlap continued. See "Vivisection had Medical Opponent.... Vaccination Figures," The Gazette, October 25, 1926; and "Vivisection, Some of its Byproducts," The Gazette, January 8, 1927. ${ }^{31}$ See the letter by G.A. (Mrs. Agnes) Stanley, "Vaccination," The Globe, August 14, 1922; "Anti-Vivisection Society Holds Its Annual Meeting”; and "Claims Vivisection Brings No Results: Speaker at Anti Meeting Makes Many Sensational Statements, Attack on Vaccination," The Globe, February 22, 1924. Even when the Society took up the matter of the use of dogs for the production of insulin, Agnes Stanley continued to harp on the issue of vaccines. She claimed that most doctors were not convinced of the benefits of serum therapy and that "through the inoculation the race is slowly being weakened by contraction of bovine syphilis contained in many vaccines and serums." Agnes Stanley, "AntiVivisection," The Globe, April 16, 1923.

${ }^{32}$ Newspapers covered Hadwen's lectures prominently: "Anti-Vivisectors were Unpopular," The Gazette, September 23, 1922; "Cruel, Brutal Says Lecturer of Vivisection"; "The Truth about Vivisection and Vaccination," Vancouver Daily World, October 4, 1922; and "Avers Serums Slew Thousands During the War," Vancouver Daily World, October 5, 1922. See also the advertisement "AntiVivisection: A free lecture will be given at the Canadian Forester's Hall," Toronto 
Daily Star, September 21, 1922. The Starwas not a supporter of the antivivisection movement, and their report of Hadwen's talk was positioned underneath a more prominent article titled "Facts, Figures Show the Value of Vivisection" and published on the following Monday.

33 “The Vaccination Question,” The Globe, February 2, 1928. The issue persisted outside of Toronto. The 1930 announcement of the creation of the new AntiVivisection Society in Winnipeg includes the doing away with vaccination among its objects. "Clubs," Winnipeg Tribune, June 24, 1930. A letter to the editor about a smallpox epidemic written by "Dora Kitto, Hon. Secretary of Canadian Antivivisection Society Victoria B.C." was published in the Ottawa Citizen as "Costly Epidemic" on December 30, 1942. A proposal that vaccinations be made compulsory in Calgary was met with objections by the Alberta Antivivisection and Human Education Society. See The Lethbridge Herald, April 26, 1950. The Animal Defence and Anti-Vivisection Society in British Columbia espoused antivaccination sentiments as late as the 1950s, arguing that vaccination was "harmful to the health and harder on the animal from which the serum is acquired.” See McMillan, “The Conflict over Animal Experimentation,” 8. ${ }^{34}$ Cronin, Art for Animals. See also Cronin's virtual exhibit, Be Kind: A Visual History of Humane Education, 1880-1945, especially the page, "Film and Lantern Slides," presented by the National Museum of Animals and Society, available at https://bekindexhibit.org/exhibition/magic-lantern-shows/.

${ }^{35}$ For reference exclusively to the laboratory in official announcements, see "Appointments made: Clinicians and Connaught Laboratory Staff Maintained by Endowments Chosen,” Toronto Daily Star, July 15, 1920; and "Varsity Saves Money by Making Serums: Connaught Laboratory Carries on Big Work in Manufacture of Antitoxins," Toronto Daily Star, December 15, 1920. References to the farm generally refer to the acreage. See "Wade Muddy Marshes for Plant Specimens," Toronto Daily Star, August 13, 1924 (an account of botanizing at the farm); and "Medicos Celebrate Opening of Institute," Toronto Daily Star, September 17, 1930. 
${ }^{36}$ For the monkey incident see "Monkey Bites Lab Worker," Ottawa Citizen, March 21, 1958. The same language is used in "Monkey Bite Very Poisonous," Nanaimo Daily News, March 21, 1958 and "Encephalitis Kills Toronto Man Bitten By Monkey," Burlington Free Press, March 22, 1958. The shift to different animal species played a role in the shifting terminology, as familiar farm animals like horses and calves were replaced by mice and monkeys, who were not naturally associated with farms. 


\section{Chapter 4}

The Herbarium: An Interior Landscape of Science

Peter Anderson

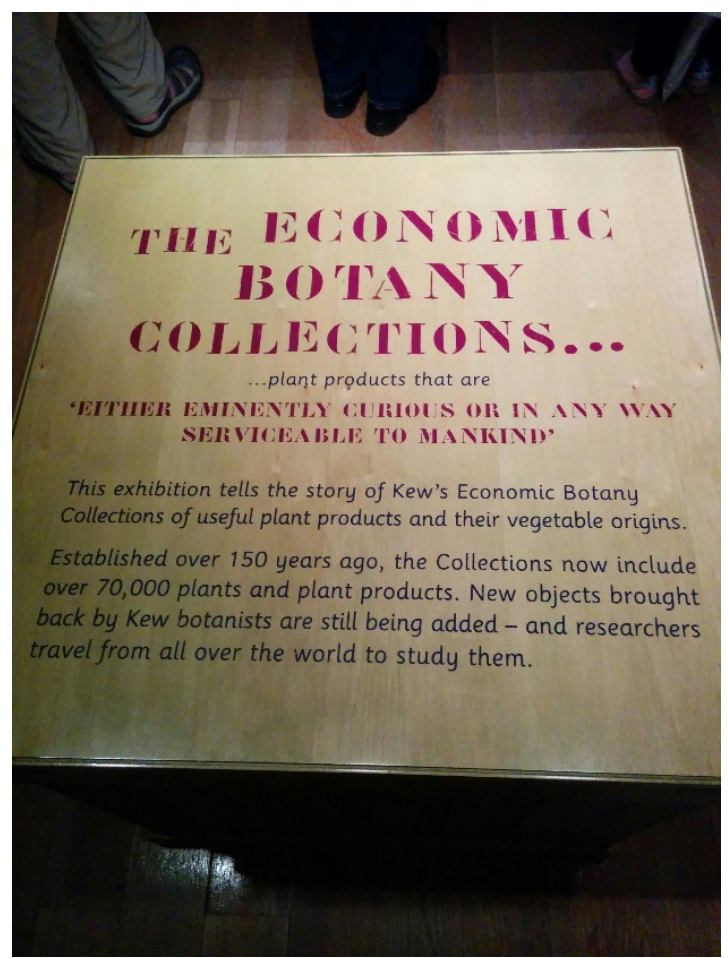

Figure 1. A plaque describing the Economic Botany Collection at Kew. Photo: Peter Anderson.

BOTANY IS A SCIENCE OF MANY PLACES. Ranging from the expeditions of Canadian governmental scientists like James Fletcher ${ }^{1}$ and Faith Fyles ${ }^{2}$ to field stations across the British Empire ${ }^{3}$, and to the network of botanical gardens centred on the Royal Botanical Gardens at $\mathrm{Kew}^{4}$, botany reached almost every corner of the globe in the late nineteenth and early twentieth 
centuries. Given the great geographical breadth and powerful colonial dynamism of botany in this era, it is easy to overlook what happened to plants after they were collected, transported, named, and planted.

Following other contributions to this volume, this chapter expands upon the historical geographies and environmental histories of science in Canada. It also looks outward to the British Empire at the end of the nineteenth and beginning of the twentieth centuries. Here I focus upon botanical collections rather than the laboratories or the field sites discussed by Stephen Bocking in his introductory essay. To discover the afterlife ${ }^{5}$ of plant specimens collected in the field, we must look at herbaria, where these specimens were preserved, stored, and interpreted according to the conventions of botanical science.

A herbarium, strictly defined, is "a collection of preserved plants stored, catalogued, and arranged systematically for study." ${ }^{6}$ Herbaria hold key positions in the production and distribution of botanic knowledge. They are far more than just storage facilities for dried plants. As systemized series of specimens, herbaria are important examples of circulating references, where the world is turned into words and knowledge is made mobile. For Bruno Latour, the circulating reference explains how a piece of the world is brought into scientific discourse: "In order to be able to say that Afulamata diasporis, a common forest plant, is found in the savanna but only in the shadow of a few forest plants that manage to survive there, she [the botanist] must preserve, not the whole population, but a sample that will serve as a silent witness for this claim." ${ }^{7}$

The circulating reference isn't every plant of a given species, but the type specimen: a single plant selected as the archetypal example of all plants of that species. Latour notes that "a text speaks of plants. A text has plants as footnotes." ${ }^{8}$ Just as the documents we use as historians reside in archival vaults, the type specimens live active afterlives in climate-controlled herbaria. Of course, not every specimen in a herbarium is a type specimen. 


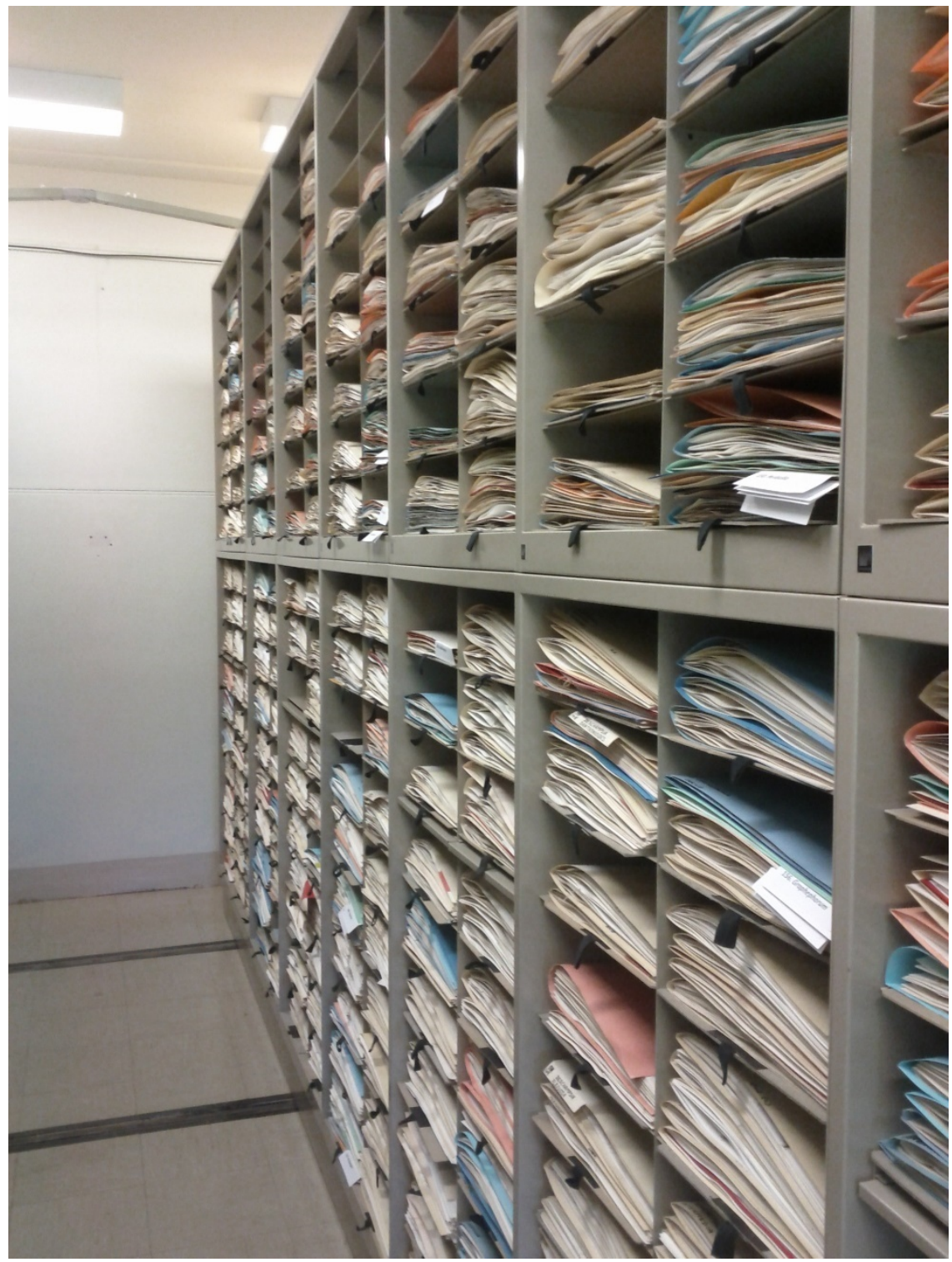

Figure 2. Part of the National Vascular Plant Herbarium in the William Saunders Building, Central Experimental Farm, Ottawa. Photo: Peter Anderson. 
Botanical expeditions that only produce one specimen of each species would fail to meet their goals. While the "discovering" institution might keep the type specimen, other specimens were shipped to other herbaria across networks shaped by contemporary imperial and scientific politics.

Collecting expeditions often produced more material than could be processed in a reasonable amount of time, creating backlogs of unidentified preserved plant material. In addition, the national collections of Britain and Canada were supplemented by donations from a variety of sources. These included other herbaria, military officers and other agents of the state, interested amateurs and field-naturalists, and farmers concerned about possible poisonous weeds in their pastures. Given the haphazard nature of these external donations, custodians of herbaria worked to control material coming into herbaria through a variety of means, including the distribution of how-to guides and manuals. "New" species are still being discovered amongst plant material collected more than a century ago.

Similar to paper documents housed in archival vaults, herbaria maintain strict climate controls to ensure the almost indefinite preservation of plant samples. The National Vascular Plant Herbarium at Ottawa's Central Experimental Farm, for example, holds samples collected by Upper Canadian author and naturalist Catherine Parr Traill. ${ }^{9}$ The NVPH's collection has its nucleus in the personal collections of James Fletcher, the first Dominion Entomologist and chief of the Canadian Experimental Farm Service's Botany Division. The herbarium of the Royal Botanic Gardens at Kew includes specimens dating as far back as the end of the seventeenth century. ${ }^{10}$

The organization of herbaria is essential to their function, and goes hand in hand with the naming of specimens. Placing related plants next to each other in the collection facilitates the discovery of relationships and the exploitation of shared properties. During a tour of the Economic Botany 


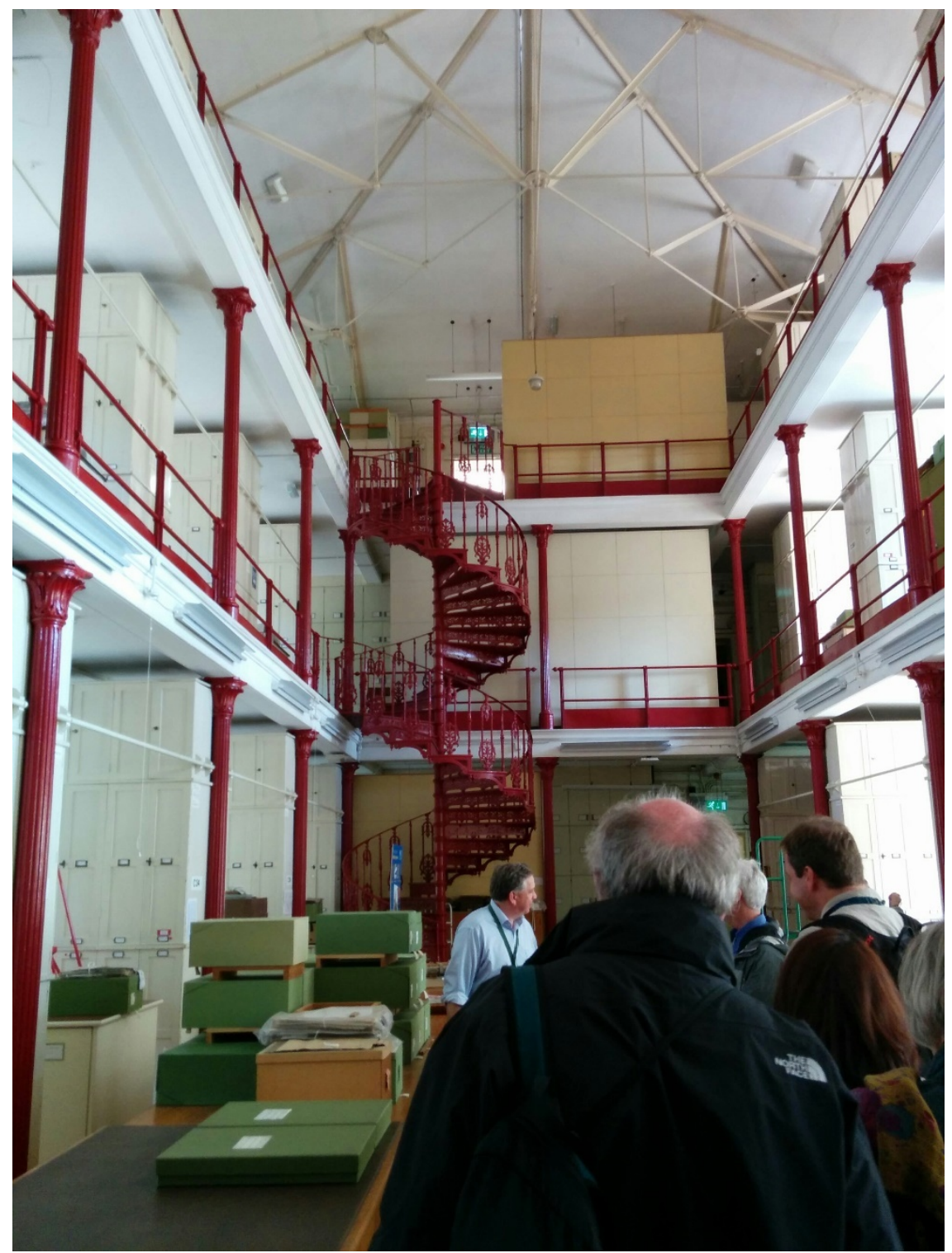

Figure 3. The Herbarium of the Royal Botanic Gardens at Kew during a study visit with the International Conference of Historical Geographers in July 2015. Photo: Peter Anderson. 
Collection at Kew as part of the International Conference of Historical Geographers in 2015, our guides described how knowing the genus of plants allowed economic botanists to explore alternatives in times of shortages, or to discover species better suited to the diverse climatic and soil conditions of different parts of the British Empire. The Economic Botany Collection is unusual in that it stores both preserved plant samples, such as the seeds of the rubber tree (Hevea brasiliensis), and a variety of end products, which demonstrate the range of industrial applications of the tree's sap.

While necessarily located in strictly controlled indoor spaces, herbaria and similar collections like "avian archives" ${ }^{11}$ provide windows onto the diverse environments of scientific practice, the politics of collection and exchange, and the importance of preservation to scientific research. Botany, as the science of plant life, isn't confined to the field, laboratory, or herbarium. It brings together a diverse collection of places, people, and plants in an attempt to know a little bit more about the more-than-human world.

${ }^{1}$ Paul W. Riegert, "Fletcher, James," in Dictionary of Canadian Biography, vol. 13, University of Toronto/Université Laval, 2003-, http://www.biographi.ca/en/bio/fletcher_james_13E.html.

${ }^{2}$ Beth Robertson, “Faith Fyles: Canadian Botanist and Painter," Innovation Storybook, Ingenium Canada, https://ingeniumcanada.org/innovation/story/faith-fyles-canadian-botanistand-painter.

${ }^{3}$ Thomas F. Gieryn's account of the "discovery" of composting in India by British scientists is illustrative. See Gieryn, "Hybridizing Credibilities: Albert and Gabrielle Howard Compost Organic Waste, Science, and the Rest of Society," in Cultural Boundaries of Science: Credibility on the Line (Chicago: University of Chicago Press, 1999), 233-335. 
${ }^{4}$ See, for example, Richard Drayton, Nature's Government: Science, Imperial Government, and the "Improvement" of the World (New Haven, CT: Yale University Press, 2000).

${ }^{5}$ But how does one determine when a plant, such as a strawberry, is actually dead? While this question is the punchline in the BBC science program The Infinite Monkey Cage, plant material, including seeds, has retained its vitality for thousands of years. See "What Is Death?", The Infinite Monkey Cage, series 8, episode 1, BBC Radio 4, June 24, 2013, http://www.bbc.co.uk/programmes/b02ykcwh; and Rachel Kaufman, "32,000year-old Plant Brought Back to Life-Oldest Yet," National Geographic News, February 23, 2012, http://news.nationalgeographic.com/news/2012/02/120221oldest-seeds-regenerated-plants-science/.

${ }^{6}$ RBG Kew, "What is a Herbarium?", http://apps.kew.org/herbcat/gotoWhatIsHerbarium.do.

${ }^{7}$ Bruno Latour, Pandora's Hope: Essays on the Reality of Science Studies (Cambridge, MA: Harvard University Press, 1999), 34.

${ }^{8}$ Ibid.

${ }^{9}$ During a tour of the NVPH, Will Knight and I asked our guide to open a cabinet marked "historical," in which Parr Traill's specimens were stored, unbeknownst to the herbarium's staff!

${ }^{10}$ William Millken, "What's in a Collection? The Herbarium at Kew," Kew Science blog, RBG Kew, https://www.kew.org/blogs/kew-science/whats-in-acollection-the-herbarium-at-kew.

${ }^{11}$ See, for example, Kirsten Greer, "Geopolitics and the Avian Imperial Archive: The Zoogeography of Region-Making in the Nineteenth-Century British Mediterranean," Annals of the Association of American Geographers 103, no. 6 (2013): 1317-31, https://doi.org/10.1080/00045608.2013.784095. 


\section{Chapter 5}

Met Techs, the Environment, and Science at the Joint Arctic

Weather Stations, 1947-1972

\section{Daniel Heidt}

STEPHEN BOCKING'S "LANDSCAPES OF SCIENCE” OUTLINES several themes that "deserve more attention in the environmental history of Canadian science." His exciting suggestions include examining how different environments impact scientific practices and material cultures, as well as how the use of science in the Canadian North after the Second World War shaped the state's ability to "administer and exploit the region."

The Canadian High Arctic provides unique opportunities to examine such questions and pose new ones. I am currently completing a history of the Joint Arctic Weather Stations (JAWS) with P. Whitney Lackenbauer. The stations were constructed between 1947 and 1950 largely at the behest and design of the American government. Canada and the US collaboratively operated a hub station at Resolute on Cornwallis Island and smaller eight-man satellite stations at Mould Bay on Prince Patrick Island, Isachsen on Ellef Ringnes Island, and Eureka and Alert on Ellesmere Island until 1972. Each of these civilian-run stations collected synoptic weather data by making surface observations and by flying weather balloons twice a day carrying radiosondes (which could be manually tracked) or rawinsondes (which could be tracked via radio-direction finding equipment) to measure temperature, barometric pressure, humidity, and wind direction. In station vernacular, both of these devices were commonly referred to as "radiosondes." The data these flights generated were crucial to military planning, civilian meteorology, and transatlantic commercial 


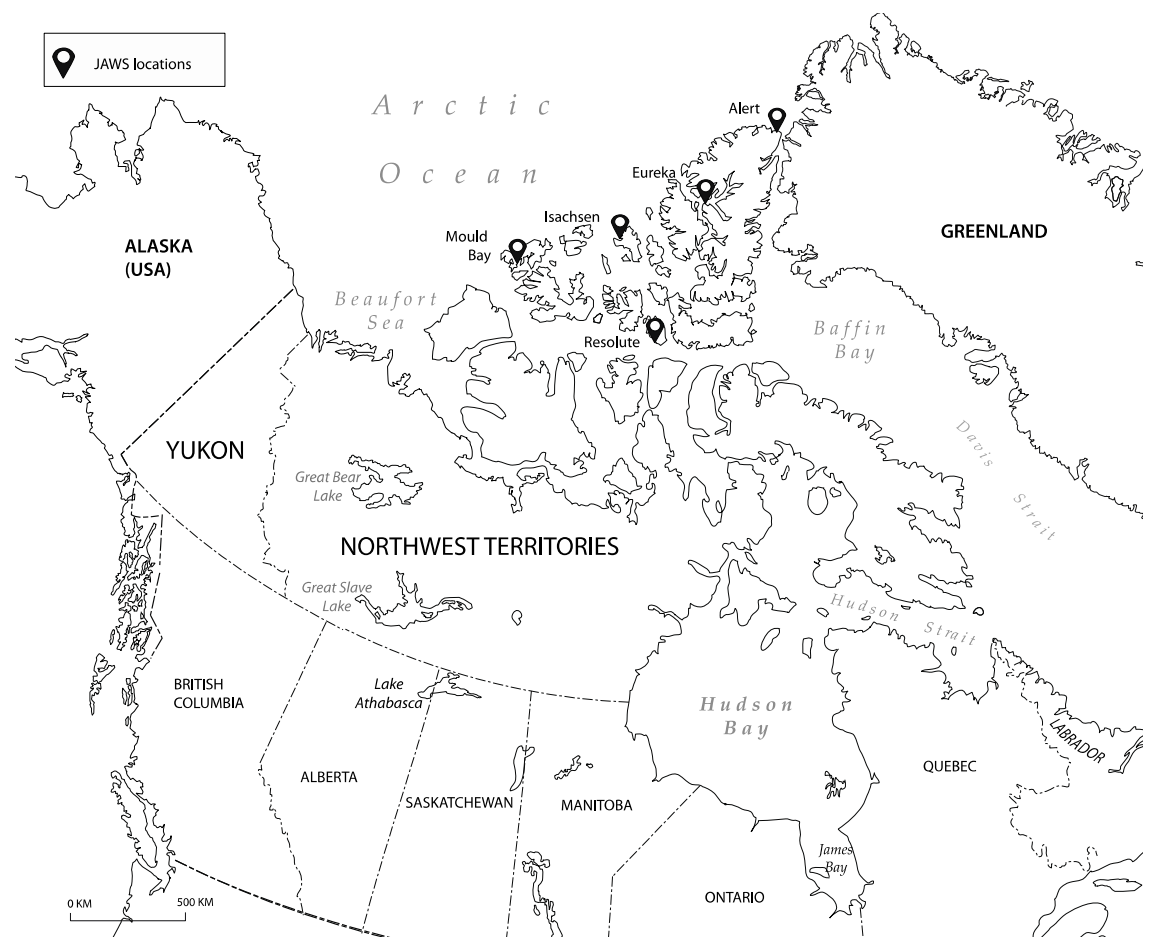

Figure 1. The Joint Arctic Weather Stations. Map courtesy of True North Consulting.

aviation, as well as North America's agricultural and forestry economies. Apart from the resupply season, these stations had little contact with the South. In fact, aside from a few hair-raising flights during the initial years of operations, aircraft did not land at the satellite stations during the dark period of the year until the 1960s.

My contributions to the book include analyzing how the High Arctic environment affected the stations' scientific cultures. The JAWS program suggests the need for historians of science and environmental historians to follow the lead of Steven Shapin and pay more attention to technicians. ${ }^{1}$ Most scholarly research focuses on the ideas, activities, and impacts of scientists or engineers with undergraduate or advanced degrees. Other academics have begun to explore how "amateurs" (such as hobbyists) 
complicated scientists' authority and contributed to environmental knowledge. ${ }^{2}$ Meteorological technicians, not scientists, conducted and encoded the JAWS programs' synoptic meteorological observations. "Met techs," as they were known, generally lacked undergraduate (let alone graduate) degrees. They were, however, professionally trained. Canadian Met Techs had to pass two courses offered by the federal Department of Transport. In the first three-month course, students learned how to conduct surface observations. The top students from this class were eligible to enroll in a rigorous four-month course in upper air observations. Neither course included Arctic curriculum. Instead, graduates received this additional operational knowledge via on-the job training at the Joint Arctic Weather Stations from outgoing Met Techs.

JAWS personnel lived in a scientific culture. They valued the powers of observation as well as accuracy, consistency, and repetition. Yet they could not analyze the data they gathered, and they were not indoctrinated to desire the placeless ideal of laboratory cultures. ${ }^{3}$ Moreover, Met Techs resided at the stations for a year or more at a time. Scientists, by comparison, typically worked at the stations for a few weeks or months. These differences led JAWS personnel to more readily accept and adapt to local conditions. The JAWS program thus offers the opportunity to compare and contrast the scientific cultures constructed by scientists and technicians in an extreme environment.

When JAWS personnel understood the importance of their activities, only the most extreme situations frustrated their perseverance. At some stations, such as Alert, balloon releases were eased by consistently low wind speeds. At other stations such as Isachsen, however, high winds regularly endangered launches by pushing released balloons sideways, dragging and pulverizing the instrument package across the station grounds. Over time, JAWS personnel used different techniques to ensure successful launches in high winds, but the most common solution was the two-person launch. 


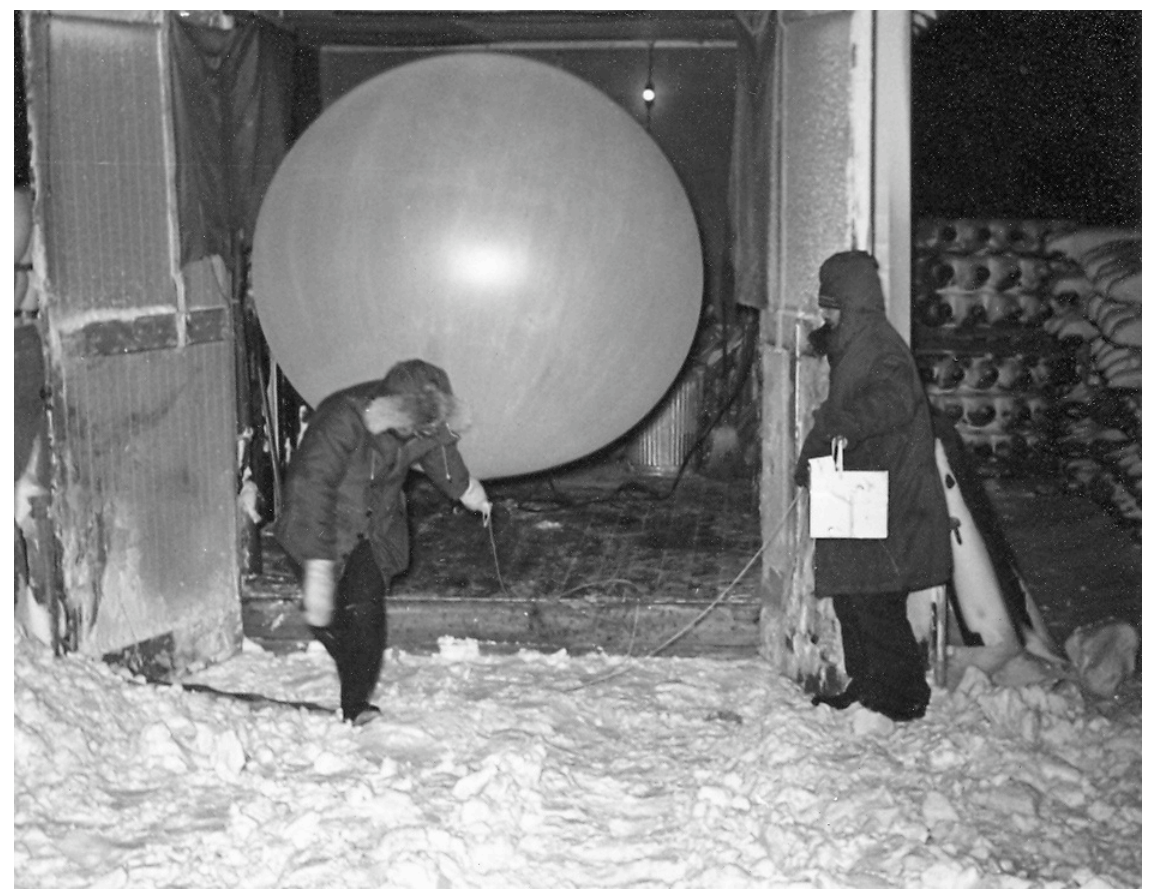

Figure 2. Preparing to launch a balloon with radiosonde after preparing them in the inflation shed at Resolute, 1949. Alan Faller personal collection.

After filling the weather balloon in the shelter and checking its attached instrument package, one person walked upwind with the radiosonde and waited until his partner released the balloon. He then ran with the radiosonde until the balloon carried its cargo aloft. According to Howard Wessbecher, who served as both a supply clerk at Resolute and then an Executive Officer at Alert in the mid-1950s, "sometimes we tried two, three releases and I'd say... less than 5\% of the time we didn't make it" and would have to concede that "hey, we can't get her up." ${ }^{4}$ In one extreme case, personnel at Isachsen launched five balloons, because the first four "burst upon hitting the sides of the door on the way out" under heavy winds. ${ }^{5}$

Radiosondes, however, were not the only types of balloons used at the stations to make meteorological observations. Smaller pilot balloons 


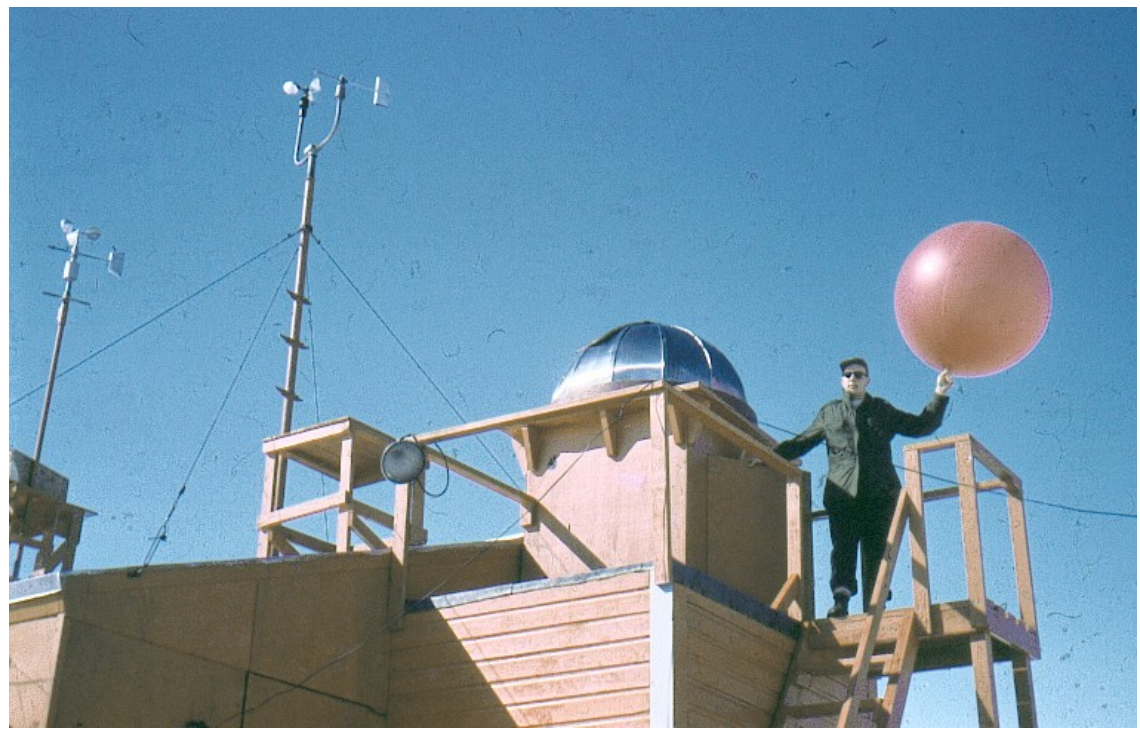

Figure 3. Lowell DeMond about to release a pilot balloon at Mould Bay, 1956. Lowell DeMond personal collection.

(pibals) were not as revealing, data-wise, as radiosondes, but they were less expensive, simpler to prepare, and useful for measuring cloud ceilings. They could also be used to determine the wind's direction and speed. Tracking the pibal flights forced observers to sit in a sheltered open-air dome and manipulate a metal theodolite with their bare hands at 30 or even 40 degrees Fahrenheit below zero. During the dark period, observers hung a candle or battery-powered light below the pibal to enhance its visibility at altitude. From time to time, the observer would note three or four identical azimuth and elevation readings and realize that he had lost the pibal and was instead fixed on a star. "This always brought about a few curses!!” former Mould Bay and Eureka Met Tech Lowell DeMond subsequently recalled. This was because a second release was necessary if the balloon had not attained the required minimum altitude. ${ }^{6}$

By the mid-1950s, station personnel began using excuses such as high winds or snow to avoid conducting pibals. Southern departmental cries 


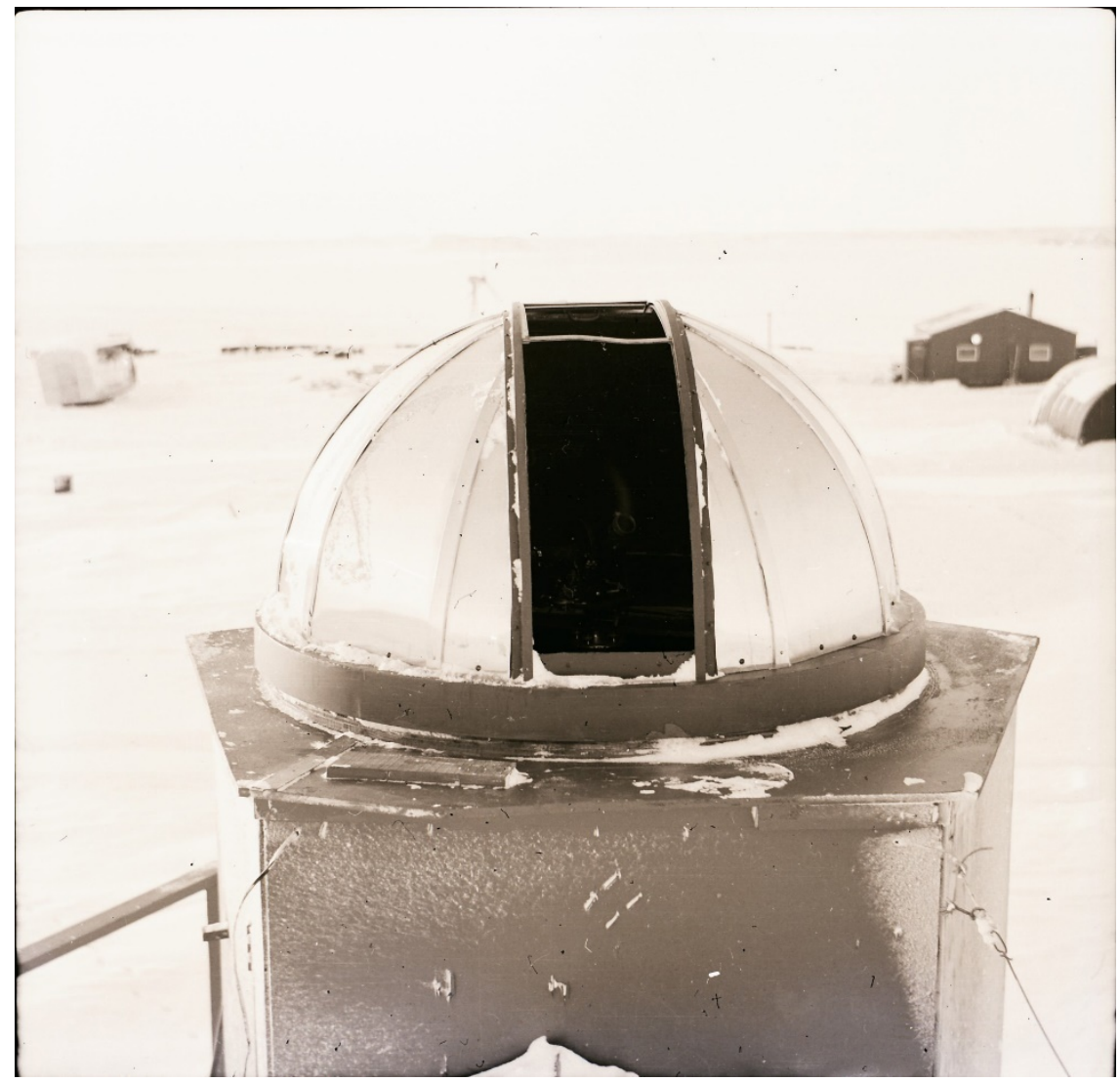

Figure 4. Isachsen's pibal dome, 1953. If you zoom in, you can see the theodolite inside the dome. Bill Nemeth personal collection.

that the flights were essential led to their strict resumption. By the 1960s, however, the regularity of these flights wavered once again. According to Larry Petznick, who was Isachsen's OIC from 1964-1965, station personnel continued "to question the value of pibal observations" and wondered "if the useage [sic] and end results from pibals are worth the amount of time and work put into them." Nevertheless, Petznick assured Canadian and American authorities that "the Pibal program continues to slog on." This seems to have been the last cry. Personnel who served at the 
JAWS stations in the late 1960s or early 1970s do not recall launching pilot balloons as part of a synoptic program.

JAWS Met Techs participated in High Arctic scientific culture, innovated operating procedures that better suited their environments, and contributed to data sets. This culture led them to persevere with a host of environmental observations, including upper air flights, despite often harsh conditions. On rare occasions, however, different understandings about the utility of their activities led them to deviate from the wishes of southern scientists. Met Techs are, of course, not unique to the JAWS program. Canada and the United States employed them at weather stations across both countries. Technicians in other professions and programs also require attention. Studying the contributions that these men (and later women) made to their varied disciplines will help social scientists to better comprehend the extent and nature of scientific culture, to understand how the practical feasibility of government programs are assessed, and to discern how non-scientists contributed to the expansion of the state in remote locations.

${ }^{1}$ Steven Shapin, "The invisible technician," American Scientist 77, no. 6 (1989): 554-63.

${ }^{2}$ See, for example, W. Patrick McCray, "Amateur Scientists, the International Geophysical Year, and the Ambitions of Fred Whipple," Isis 97, no. 4 (2006), 63458, https://doi.org/10.1086/509947; and Thomas R. Williams, "Getting Organized: A History of Amateur Astronomy in the United States" (PhD diss., Rice University, 2000).

${ }^{3}$ For further discussion on "placing" laboratory cultures, see David N.

Livingstone, Putting Science in Its Place: Geographies of Scientific Knowledge (Chicago: University of Chicago Press, 2003), https://doi.org/10.7208/chicago/9780226487243.001.0001.

${ }^{4}$ Howard Wessbecher interviewed by Brian Shoemaker, April 20, 2000, Polar Oral History Project, The Ohio State University, 
https://kb.osu.edu/dspace/bitstream/handle/1811/32171/1/WessbecherTranscr ipt.pdf.

${ }^{5}$ John Llewellyn, “Monthly Station Activity Report - December, 1965," January 15, 1966, Library and Archives Canada (LAC), RG 93, box 821, file 6754-1291, pt. 19.

${ }^{6}$ Lowell DeMond, email message to author, May 23, 2013.

7 "Monthly Station Activity Report, Isachsen, NWT," May 2, 1965, LAC, RG 93 , box 821, file 6754-1291, pt. 19 . 


\section{Chapter 6}

Domesticating Poliovirus: Laboratory Monkeys and Vaccine Production

\section{Liza Piper}

VACCINES ARE A TECHNOLOGY-a form of artifice-that reproduce the biological consequences of a first, authentic historical encounter between an individual and a virus, or a community and a virus by means of largescale vaccination campaigns. ${ }^{1}$ The artifice of vaccination depends entirely on the manipulation of nature. Vaccines are, after all, made from pathogens themselves. In anti-vaccination writings, authors focus on the unnatural additives to vaccines: the mercury (thimerosal) used as a preservative, the formaldehyde used to inactivate viruses and toxins, and the aluminum that is used as an adjuvant. ${ }^{2}$ Yet the use of the viruses themselves is just as remarkable. The process of polio vaccine production, for example, is a process of domestication as much as a process of fabrication. Within the landscapes of laboratories and across the topographies of animal bodies, wild polioviruses are taken and transformed into viruses under human control, which can then be deployed in large-scale vaccination programs. Sometimes, new viruses literally evolve out of the research process leading up to vaccine production, as with a neural-adapted, virulent strain of polio called the MV strain affecting only the central nervous system and no longer replicating in the intestines. ${ }^{3}$ In a 1974 interview with Saul Benison, Albert Sabin spoke with some regret about early work he had done using the MV strain, rather than "strains as they are found in nature, before they have been changed by many passages in the laboratory." He referred to 


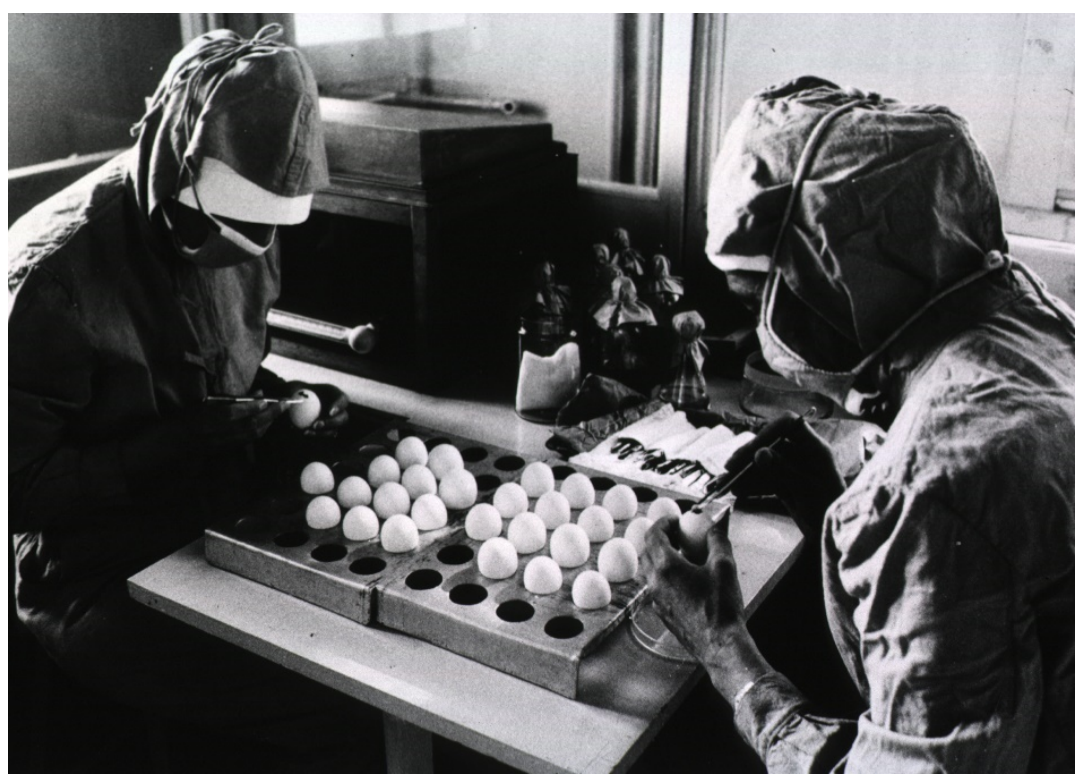

Figure 1. Preparation of measles vaccine at the Tirana Institute of Hygiene and Epidemiology, Tirana, Albania, c.1969-1979. WHO / D. Henrioud (Photographer).

strains including $\mathrm{MV}$ and others transformed in the laboratory as "artifacts" that were used out of ease, but did not permit conclusions about the "human disease or the original virus."

Other-than-human nature is subjugated in many different ways in vaccine research and production. To grow viruses needed for vaccines outside of the human body historically required other bodies. The classic example of their deployment was Edward Jenner's use of pus from cowpox blisters (albeit found on the hands of milkmaids, but contracted originally from cows) to inoculate against smallpox. Fertilized chicken eggs are used to grow vaccine strains of influenza, and historically limited supplies of fertilized chicken eggs impeded rapid vaccine production. ${ }^{5}$

In the case of polio, monkeys were essential to biomedical research. Unlike most other laboratory animals (rabbits, guinea pigs, and mice), they were susceptible to polioviruses and were therefore essential for laboratory 


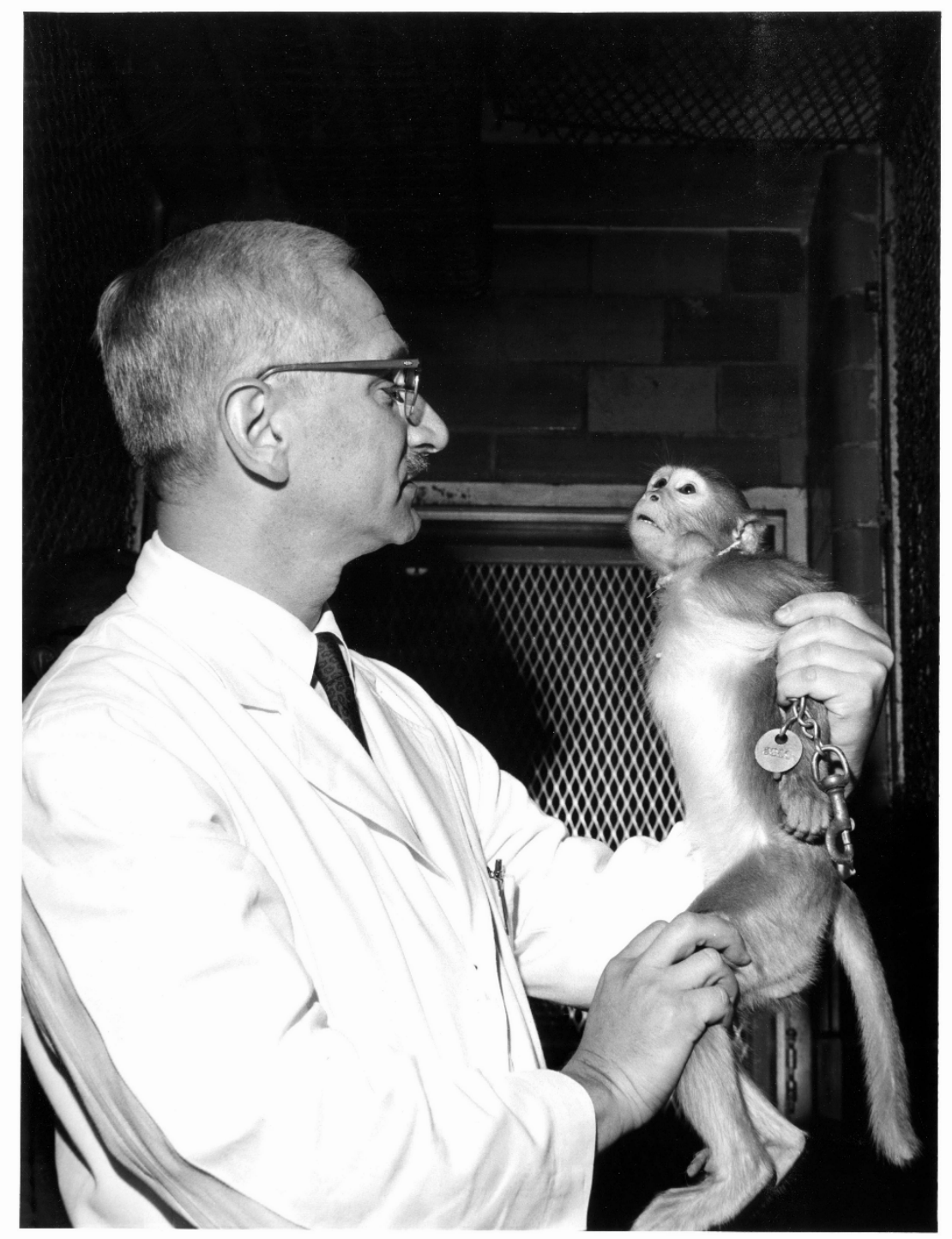

Figure 2. Albert Sabin and a research monkey, c.1950s. Courtesy the Hauck Center for the Albert B. Sabin Archives, Henry R. Winkler Center for the History of the Health Professions, University of Cincinnati Libraries. 
research on the disease. Indeed, they shaped the conditions of research into polio from 1908 until 1939. This included the need to transport monkeys during polio epidemics, as when seventy-five travelled by train with researchers to Los Angeles to investigate an outbreak there in $1934 .{ }^{6}$ By 1939, a mouse-adapted strain (the Lansing strain) of polio had been isolated that permitted some experimental effort to be diverted from monkey to mouse bodies.

Research undertaken between 1948 and 1955 at first promised to free monkeys entirely from their role in poliovirus research, but ended up greatly amplifying demand for their bodies. Researchers had attempted to grow poliovirus in vitro, "artificially" or "outside of the body," with varying degrees of success since the 1910 s. $^{7}$ Then, in a 1949 article published in Science, John Enders, Thomas Weller, and Frederick Robbins described cultivating the Lansing strain in tissue cultures made from human embryos, including non-nervous tissues. This research demonstrated conclusively that polio was not exclusively a disease of the central nervous system. ${ }^{8}$ More importantly, this work, by enabling virus reproduction in tissue cultures-a preparation made from living tissue to serve as an artificial medium for cell growth-liberated polioviruses from bodies, whether monkey, mouse, or human. This was a precursor to the mass reproduction of domesticated poliovirus strains needed for large-scale vaccine trials.

The creation of ambiguous boundaries between nature and laboratorybased artifice was central to the domestication of polioviruses, as seen with the evolution of laboratory-born poliovirus strains. The development of tissue cultures in turn moved much of the work from monkey bodies into test tubes and Povitsky bottles. But tissue cultures also needed to be kept and fed in conditions that closely approximated those experienced by living bodies. Techniques used by Jonas Salk and colleagues in his Pittsburgh 


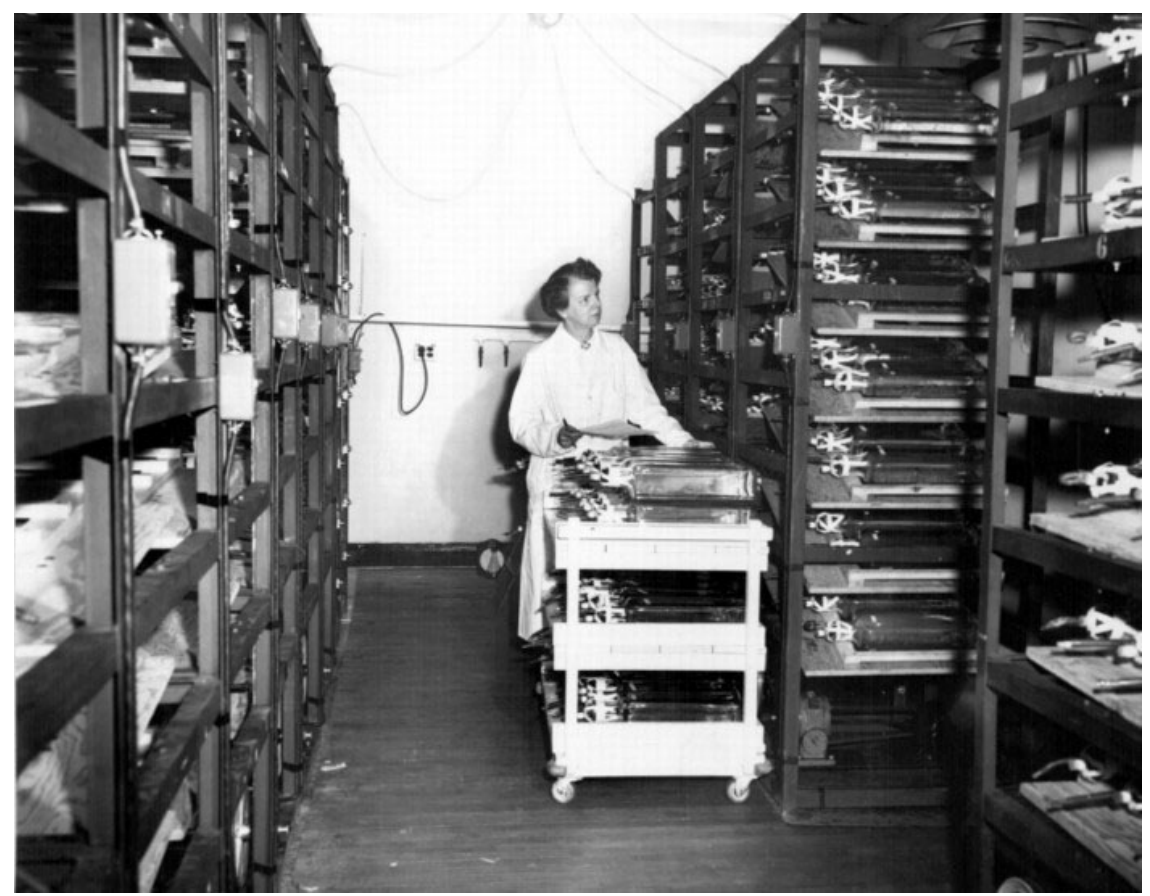

Figure 3. Dr. Leone Farrell and the "Toronto method" of poliovirus cultivation,

Connaught Laboratories, 1953-1954. Sanofi Pasteur Canada (Connaught Campus)

Archives, Toronto.

laboratory drew on a method developed by George Otto Gey, which kept the tissue culture in motion, rocking it back and forth like a sleeping baby, exposing it alternately to air and food. ${ }^{9}$ The human embryonic tissues used by Enders, Weller, and Robbins were expensive and difficult to procure, however. By 1951, Salk and his colleagues had refined a technique to produce tissue cultures from monkey kidney cells for propagating large volumes of poliovirus. Salk and his colleagues used a nutrient solution called Medium 199, synthesized at the University of Toronto's Connaught Laboratories. It contained over sixty ingredients ranging from vitamins to table salt, and included experimental amino acids, cell surface agents, nucleic acids, growth factors, and iron. The medium kept the tissue culture cells alive long enough to be infected by the virus, which was then allowed 
to multiply until the cells were completely destroyed, leaving only the poliovirus suspended in a solution of Medium 199. ${ }^{10}$

John R. Paul, medical historian and polio researcher, had reflected that with Enders, Wellers, and Robbins' work, it was "wonderful to say, ... that at long last monkeys, which had been so essential in the poliomyelitis laboratory, could be replaced by tissue cultures, for certain purposes at least. This marked an end, at least partially, of the monkey era." ${ }^{11}$ Partially is the operative word here. Monkeys continued to be used in laboratories, even if research no longer depended on them. More important, the tissue cultures that replaced living animals had to be manufactured from monkey bodies. Really, then, this simply marked a shift from dealing with whole monkeys to monkey parts. Indeed, the scale of monkey harvesting increased dramatically in the context of vaccine production. Thus the 1949 article by Enders, Weller, and Robbins can be seen as changing experimental conditions for virology in general by leading to "the largescale employment of nonhuman primates in the virus laboratory," as well as paving the way for the manufacture of a polio vaccine. ${ }^{12}$

In 1953, the National Foundation for Infantile Paralysis requested that the Connaught Medical Research Laboratories in Toronto assist in the preparation of virus fluids (infected tissue cultures) needed for the American trials of Salk's vaccine. Scientists at Connaught had first engaged in poliomyelitis research in the late 1930s. Researchers were based either at the University of Toronto campus in downtown Toronto, Ontario, or out at what was initially called "the Farm"-a fifty-eight-acre property on the northern outskirts of the city. Both were essential landscapes of medical science in Canada, as Joanna Dean has also described in her chapter in this volume. The Farm was renamed the Dufferin Division after Princess Alice, Countess of Athlone, visited in 1943 and commented that the work was not what she expected of a "farm." ${ }^{13}$ 


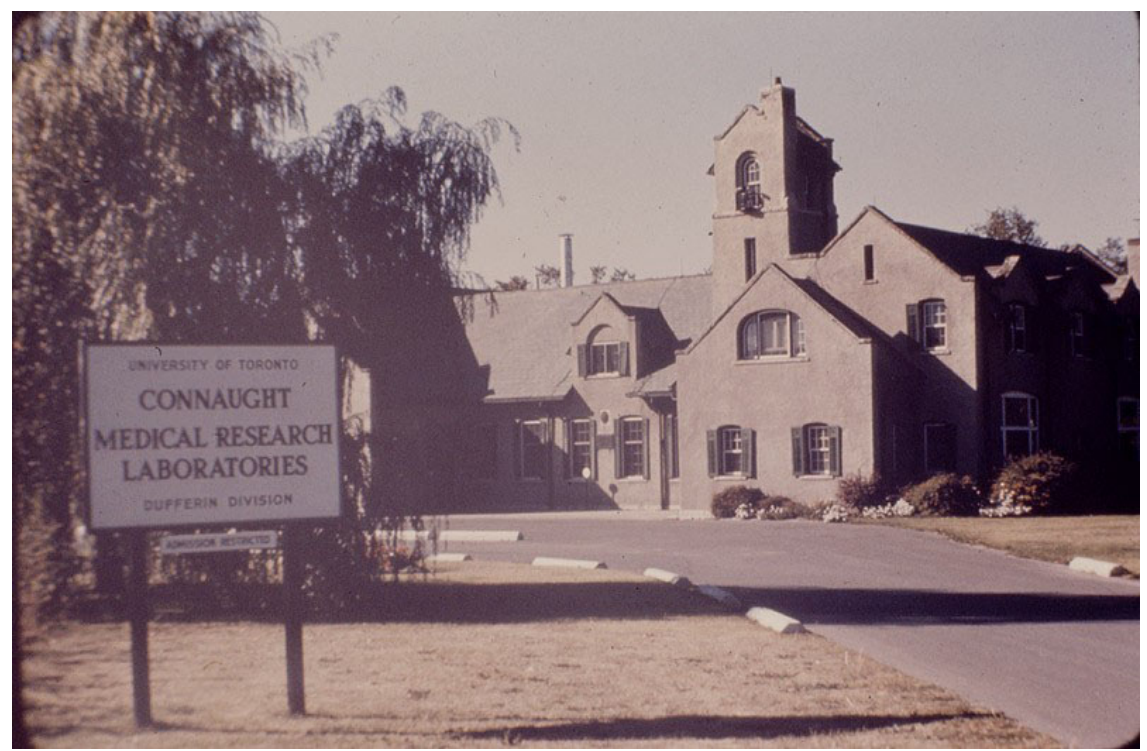

Figure 4. Dufferin Division of the Connaught Medical Research Laboratories (after the name change), 1940s. Sanofi Pasteur Canada (Connaught Campus) Archives, Toronto.

At the Farm, horses were kept for the preparation of diphtheria antitoxin, which required injecting and bleeding the horses as well as facilities for refining and concentrating the antitoxin. Calves were kept for the manufacture of smallpox vaccine, and cows for the manufacture and testing of "beef" liver extracts, used in the regeneration of hemoglobin. Insulin was prepared from an alcoholic extract of minced pancreas glands of cattle or hogs. Cows were also used for research into bovine tuberculosis. The Farm housed colonies of guinea pigs, white mice, and rats. Its buildings featured animal operating theatres, laboratories, housing for staff and researchers, and some veterinary research facilities. ${ }^{14}$ Other manufacturing facilities and laboratories were located downtown in the University of Toronto's Department of Hygiene, including cages for monkeys. ${ }^{15}$ By the 1950s, when poliomyelitis vaccine development was at its peak, the monkeys too were moved out to the Farm. 
In 1953, workers and scientists at Connaught prepared 5,521 litres of virus fluids that year, using over 7,000 monkeys in their production. ${ }^{16}$ In 1954, the stables at the Dufferin Division were renovated to accommodate monthly shipments that had grown to as many as 1,500 monkeys. This enormous increase in demand for monkeys came not only from the Connaught Laboratories themselves, but also from laboratories across North America that were racing to develop an effective vaccine at the height of polio epidemics. Rhesus macaques were the animal of choice because their kidneys could be used for tissue cultures and because they were relatively easy to procure from dealers in India. Then, in 1955, concerned about these animals' deaths and the poor conditions they encountered in transport, India imposed an export embargo on macaques. ${ }^{17}$ The importance of these monkeys to polio vaccine development led to political pressure from the United States and the United Kingdom. Both countries pushed India to reopen the trade on the condition that the monkeys be treated humanely and be used exclusively for medical research and vaccine production. ${ }^{18}$ In the context of societal anxiety over polio, Neel Ahuja has argued "that national officials [in the US] in charge of marshalling 'research resources' established the rhesus as the primary biomedical model for the human to be imported and preserved as a vital national resource." ${ }^{19}$

Even as rhesus macaques were becoming a biomedical model for humans, they were animals in their own right, needing care and treatment. Through the 1970s some continued to express concern that appropriate conservation measures were not being observed in the capture of macaques and other species earmarked for research purposes at the National Institutes of Health, and at private pharmaceutical research labs like the Connaught. There was also concern about the hazards posed by monkey bodies. In a 1971 review of the role of primates in virology, S.S. Kalter and 
R.L. Heberling emphasized that "monkeys and apes must not be considered simply as 'test tubes'... but as biological entities harboring a multitude of microbial and parasitic forms." ${ }^{20}$ Certain microbes and parasites were encouraged by the trade and commerce in monkeys for experimentation. Tom Rivers, a leading American virologist at the Rockefeller Institute, described how

[m]any investigators, in order to cut costs, would sell their monkeys to dealers if they survived given experiments and appeared hale and hearty. The dealers, in turn, would resell the monkeys to other laboratories. Under such conditions, an investigator could buy a monkey from a dealer and have no reason to suspect that the animal had ever seen a poliovirus when, in fact, it may have had all three types of poliovirus. And how was one to know at that time which type or combination of types it had had? No one knew about types. You can imagine how cockeyed some of the experimental results were, and they were cockeyed! ${ }^{21}$

Kalter and Heberling emphasized that practices for the capture, shipping, and handling of non-human primates encouraged the spread of viruses between monkeys, and even across different monkey species. They noted that even when animals were trapped individually, they were then kept until shipment in gang cages, where viruses could readily be transmitted between animals. Likewise, cages that were not cleaned properly between shipments could harbour viruses and bacteria that could infect more recently trapped animals. Conditions in the exporting and importing countries were, these authors noted, "generally unhygienic," with little attempt made to observe public health or sanitary practices. "Frequently," they wrote, "the problem of organism interchange is 
compounded in the importers' holding areas as different species from all over the world are now brought together." 22

Beyond the "cockeyed" research results Rivers described, the use of monkey kidneys for tissue culture, when combined with researchers' inattention to the monkeys as disease carriers in their own right, had serious implications in the development of the polio vaccine. Monkey bodies were far from sterile test tubes, and over time, researchers became more aware of the dangers posed by indigenous monkey viruses. In 1932, William Brebner, a bacteriologist at the Rockefeller Institute working on poliomyelitis and a colleague of Albert Sabin, was infected and died after being bitten by a macaque. The virus he succumbed to was later identified as Herpes B (for Brebner), and the infectious agent became generally known as "virus B." ${ }^{23}$ Given that this virus had been discovered in the process of poliomyelitis research, those involved in the development of vaccines using monkey kidney tissues recognized the possible presence of the virus in vaccines. They conducted significant testing, therefore, to ensure that the "virus was inactivated more quickly by the amount of formaldehyde used in preparing the vaccine than polioviruses and that no danger existed." ${ }^{24}$ But virus B was by no means unique. As Kalter and Heberling described almost twenty years later, there were numerous potential viruses that existed in monkeys at the point of capture, or which could be transmitted under the conditions in which they were transported. Some of these viruses would go on to infect the tissue cultures, with visible effect: researchers had to dispose of waste tissue cultures and vaccines as part of the manufacturing process. One virus, later called Simian virus 40 (SV40), did not cause sickness in infected macaques, but has since been linked to the development of mesothelioma, osteosarcoma, and ependymoma cancers in humans. Polio vaccines produced between 1955 
and 1963 are thought to have been widely contaminated with SV40, due to the use of infected monkey kidney tissues. ${ }^{25}$

Studying the process of vaccine discovery and production involves tracing the experiences of polioviruses into laboratories. In these landscapes of science, we see the domestication of polioviruses and the evolution of new poliovirus strains as a result of laboratory research conditions. We also see the role of monkeys in enabling the domestication of such viruses, and latterly, the liberation of domesticated polioviruses from the topographies of human and other-than-human bodies through the development of tissue cultures. This liberation led to an intensified dependence on monkeys as source material for substrate, rather than as living organisms. This narrowed focus on partial, rather than whole monkeys made possible the development of a vaccine that was fundamental to human control of wild polioviruses.

${ }^{1}$ The name "vaccine" comes from the Latin term for "cow" (vacca), since the first vaccine was made from fluid from a cowpox pustule on a milkmaid's wrist. This infectious matter was inoculated into a boy, who thereafter had immunity to smallpox. Although the boy had not previously encountered the relevant pathogen, the vaccine had reproduced or mimicked such an encounter within the boy's body, yielding the biological reaction needed to confer immunity. Modern vaccination programs multiply such encounters to encompass entire communities.

Thanks to Chris Sellers for this insight into vaccines as a technology. ${ }^{2}$ Adjuvants are substances added to a vaccine to enhance the body's immune response. For an example of such anti-vaccination writing, see Janine Roberts, "Polio: the Virus and the Vaccine," special report in The Ecologist 34, no. 4 (2004): 35-52.

${ }^{3}$ Naomi Rogers, Dirt and Disease: Polio before FDR (New Brunswick, NJ: Rutgers University Press, 1996), 24. 
${ }^{4}$ Transcript of interview of Albert B. Sabin conducted by Saul Benison, March 2, 1974, tape 2, pp. 57-58, Albert B. Sabin Archives, Henry R. Winkler Center for the History of the Health Professions, University of Cincinnati Libraries, http://hdl.handle.net/2374.UC/701637.

${ }^{5}$ George Dehner, Influenza: A Century of Science and Public Health Response (Pittsburgh: University of Pittsburgh Press, 2012), 63, 166.

${ }^{6}$ Gareth Williams, Paralysed with Fear: The Story of Polio(Basingstoke: Palgrave Macmillan, 2013), 103, https://doi.org/10.1057/9781137299765.

${ }^{7}$ John R. Paul, A History of Poliomyelitis (New Haven and London: Yale University Press, 1971), 372; A.B. Sabin and P.K. Olitsky, "Cultivation of Poliovirus in vitro in Human Embryonic Nervous Tissue," Proceedings of the Society for Experimental Biology and Medicine 34, no. 3 (1936): 357, https://doi.org/10.3181/00379727-34-8619c.

${ }^{8}$ This work also led to Enders, Weller, and Robbins sharing the 1954 Nobel Prize in Physiology or Medicine. See

http://www.nobelprize.org/nobel_prizes/medicine/laureates/1954/.

${ }^{9}$ For the role of Gey and HeLa cells in polio research, see Rebecca Skloot, The Immortal Life of Henrietta Lacks (New York: Crown Publishers, 2010), 93-97. ${ }^{10}$ Christopher James Rutty, “Do Something!... Do Anything!’: Poliomyelitis in Canada 1927-1962” (PhD diss., University of Toronto, 1995), chap. 7.

${ }^{11}$ Paul, History, 374.

12 S.S. Kalter and R.L. Heberling, "Comparative Virology of Primates," Bacteriological Reviews 35, no. 3 (1971): 311, https://doi.org/10.1007/978-14615-8990-7_6.

${ }^{13}$ Robert D. Defries, The First Forty Years, 1914-1955, Connaught Medical Research Laboratories, University of Toronto (Toronto: University of Toronto Press, 1968), 209.

${ }^{14}$ Ibid., 28-29, 41-42, 96, 314-17.

${ }^{15}$ P.A. Bator and A.J. Rhodes, Within Reach of Everyone: A History of the

University of Toronto School of Hygiene and the Connaught Laboratories, vol. 1 (Ottawa: Canadian Public Health Association, 1990), 176. 
${ }^{16}$ Defries, Forty, 273.

${ }^{17}$ For more details, see Deborah Rudacille, The Scalpel and the Butterfly: The Conflict between Animal Research and Animal Protection (Berkeley and Los Angeles: University of California Press, 2000), chap. 5; and Andrew N. Rowan, $O f$ Mice, Models, and Men: A Critical Evaluation of Animal Research (Albany: State University of New York Press, 1984), 115.

${ }^{18}$ Rowan, Mice, 115. See also UK Hansard HC Deb 25 April 1955, vol. 540, cc620-4, http://hansard.millbanksystems.com/commons/1955/apr/25/poliomyelitisvaccine-1.

${ }^{19}$ Neel Ahuja, "Macaques and Biomedicine: Notes on Decolonization, Polio, and Changing Representations of Indian Rhesus in the United States, 1930-1960,” in The Macaque Connection: Cooperation and Conflict between Humans and Macaques, ed. Sindhu Radhakrishna, Michael A. Huffman, and Anindya Sinha (New York: Springer, 2013), 72, https://doi.org/10.1007/978-1-4614-3967-7_5. ${ }^{20}$ Kalter and Heberling, "Virology," 311.

${ }^{21}$ Saul Benison, ed., Tom Rivers: Reflections on a Life in Medicine and Science (Cambridge: MIT Press, 1967), 255.

${ }^{22}$ Kalter and Heberling, "Virology," 314-15.

${ }^{23}$ Jason D. Pimentel, “Herpes B virus - 'B' is for Brebner: Dr. William Bartlet Brebner (1903-1932)," Canadian Medical Association Journal 178, no. 6 (2008): 734, https://doi.org/10.1503/cmaj.071098.

${ }^{24}$ Defries, Forty, 279.

${ }^{25}$ For more on monkey viruses and vaccine production, see Keerti V. Shah, “Simian Virus 40 and Human Disease," Journal of Infectious Diseases 190, no. 12 (2004): 2061-64; and Debbie Bookchin and Jim Schumacher, The Virus and the Vaccine: The True Story of a Cancer-Causing Monkey Virus, Contaminated Polio Vaccine, and the Millions of Americans Exposed (New York: St. Martin's Press, 2004). See also the Public Health Agency of Canada's webpage on Polio Vaccine and SV40: http://www.phac-aspc.gc.ca/im/polio-eng.php. 


\section{Conclusion}

Landscapes of Science: Placing Knowledge, Displacing Nature

Stephen Bocking

THESE ESSAYS EXAMINE MANY ASPECTS OF SCIENCE: who does it, and why; what objects are observed, measured, and manipulated (or ignored); how scientists fuse nature and culture to form new phenomena. But central to these accounts are the places of science. Evidently, what we know about nature is shaped by where we know it. Hence the promise of bringing together the history of science and environmental history, as a way of learning how knowledge has been entangled with Canadian spaces and places.

And it's especially interesting to use these essays to consider several places alongside one another: to look at what was done amidst Arctic winds, Georgian Bay breezes, the sounds and smells of the laboratory, or the stillness of the herbarium. One thing we learn is the value of examining knowledge-observations, instrumental data, objects collected or synthesized-in relation to the people and practices that formed them. At the lake scientists sampled fish. Up north technicians launched balloons. Over in the lab researchers extracted samples from animals. Behind the doors of the herbarium curators stored and ordered fragile specimens. Like knowledge, these practices were diverse and evolving, shaped by local attitudes, circumstances, disciplines, technologies, and practical concerns. Nature's agency was also always present, even-and sometimes especially-when scientists struggled to impose control. 
These practices also illustrate how transforming experience into knowledge means making choices about what to include and exclude. These places were sites of sensation: cold winds or warm sun, the quiet herbarium, the smells of the lab. Some of this sensory information-mainly, what was seen-was extracted, mobilized and became knowledge. The rest remained fixed in place, perhaps becoming merely anecdotes of the working day.

These essays also demonstrate the value of locating the places of science within larger spaces of human and nonhuman activity. Technicians relocated to the Arctic because meteorologists decided that the region was an essential element of global weather systems. Biologists saw Georgian Bay as a window onto Great Lakes fish communities. Herbaria functioned within global networks of movement and storage. In each place, observations extended beyond what could be sensed directly, and scientific practices, although located in particular places, were framed in relation to and influenced by larger contexts.

One way we might think about these places and how they relate to larger spaces is as sites of exchange: between humans and the rest of nature, or between local places and spaces elsewhere, through networks defined by the movement of people, knowledge and power. As sites of exchange these places became linked to the geographies of Arctic weather systems, Great Lakes fish populations, the commercial production of vaccines, and imperial networks enabling movement of useful plant species. But boundaries also restricted such exchanges, including between humans, as when Indigenous people were excluded from Go Home Bay-a case of boundaries enforcing the place of science within the larger spaces of settler colonialism.

Scientific practices were also about making claims that would be taken as true, exemplifying the significance of credibility to the history of modernity. The point was to be persuasive: that instruments on balloons 
truly described Arctic weather, that vaccines would work as they should, or that collections exemplified the diversity of life (and not just what happened to catch the collector's eye). So along with knowledge, trust was also being constructed. But there's no single recipe or rulebook for this. Scientists in laboratories create trust by imposing standard practices and firm boundaries (in theory, if not always in practice) between their workspaces and the outside world. Knowledge produced there is thus rendered "timeless" and "placeless." In contrast, scientists and technicians in field sites invoke the authenticity of nature: truth comes from being out in the world. Both views are represented in these essays.

But as these essays also show, scientists, like other humans, can have varied motives. In these places it wasn't just about the science. Go Home Bay was far from the city's noise and dirt, and promised relaxation and solitude. Technicians pursued into the Arctic both their own interests (good pay, advancement) and those of their institutions (military and commercial demands for accurate weather forecasting). The vaccine laboratory was located at the intersection of disease protection, commercial benefit, and demands for safety and efficacy; it blurred the boundary between laboratory and factory. Plant collectors harvested pleasure along with their specimens, while the herbaria that accumulated their finds anchored networks of agricultural improvement.

These diverse motives illustrate how science operates in several registers. One is the manipulation of materials: measuring, moving, mixing, transforming. Another is the social consequences of these activities, with science embedded in networks of economic and political relations, often creating new places and forms of life. In these various ways, science has been implicated in key episodes in the environmental history of Canada.

These essays examine case studies that took place before humans had reached quite so deeply into the stuff of life-before engineered genes, 
endocrine disruptors, nanomaterials, and other substances about which we still lack full understanding-or quite so widely, with our ongoing transformation of the globe's atmosphere, oceans, and lands. Novel scientific practices, from computer models to remote sensing to genomic analysis, were also still beyond the horizon, or just coming into view. So were ideas about the social responsibility of science and its relations with other ways of knowing, including Indigenous knowledge. From our own position deep in the Anthropocene we might look back almost nostalgically at these tentative forays-at least until we recognize in them the origins of our current predicament. 
Tina Adcock is an assistant professor of history at Simon Fraser University and a cultural and environmental historian of modern Canada. She has commissioned and edited five special series for The Otter La loutre, NiCHE's blog, since 2015.

Peter Anderson is an Ottawa-based public history consultant and historical geographer of science. His research examines the confluence of government science, politics, and landscape change in Canada. He is currently working on a project that excavates Canadian soil science.

Stephen Bocking is with the School of the Environment at Trent University, Peterborough, Ontario. He teaches courses on science and politics, environmental history, and global political ecology. He has a special interest in the history of environmental knowledge.

Joanna Dean is an associate professor in the History department at Carleton University where she teaches animal history and environmental history. She co-edited, with Darcy Ingram and Christabelle Sethna, Animal Metropolis: Histories of Human-Animal Relations in Urban Canada (University of Calgary Press, 2017).

Daniel Heidt is the author of several academic articles on Arctic science, sovereignty, and logistics during the Cold War. With P. Whitney Lackenbauer, he is editor of Two Years Below the Horn: Operation Tabarin, Field Science, and Antarctic Sovereignty (2017). He is currently 
co-editing a volume with Stephen Bocking entitled Cold Science: Arctic Science in North America During the Cold War, 1945-1991.

Liza Piper is an associate professor of history at the University of Alberta in Edmonton where she teaches environmental history and the histories of northern and western Canada. Her publications include The Industrial Transformation of Subarctic Canada (2009) and Environmental Activism on the Ground: Small Green and Indigenous Organizing (2019), co-edited with Jon Clapperton.

William Knight is curator of agriculture, food, and fisheries at Ingenium: Canada's Museums of Science and Innovation in Ottawa. He has a PhD in Canadian history from Carleton University. 


\section{LANDSCAPES OF SCIENCE}

"These essays examine many aspects of science: who does it, and why; what objects are observed, measured, and manipulated (or ignored); how scientists fuse nature and culture to form new phenomena. But central to these accounts are the places of science. Evidently, what we know about nature is shaped by where we know it. Hence the promise of bringing together the history of science and environmental history, as a way of learning how knowledge has been entangled with Canadian spaces and places." — Stephen Bocking

\section{NiCHE}

Network in Canadian History and Environment

Department of History

York University

2140 Vari Hall

4700 Keele Street

Toronto, Ontario, M3J 1P3

http://niche-canada.org

Adcock, Tina. Ed. Landscapes of Science. Toronto: Network in Canadian History and Environment, 2018.

Landscapes of Science edited by Tina Adcock is licensed under a Creative Commons Attribution-NonCommercial 4.0 International License.

\section{The Otter La loutre E-book Series}

Editors: Tina Adcock, Sean Kheraj, and Daniel Macfarlane

Layout: Sean Kheraj

Design Consultant: Will Knight

This occasional open-access series collects and preserves the best writing published on The Otter La loutre, NiCHE's blog. Its thematic anthologies feature short pieces that examine the historical relationships among people and the rest of nature in Canada. 